\title{
GEOHYDROLOGY AND MODEL ANALYSIS FOR WATER-SUPPLY MANAGEMENT IN A SMALL AREA OF WEST-CENTRAL KANSAS
}

\section{U.S. GEOLOGICAL SURVEY}

Wa:er-Resources Investigations 80-91

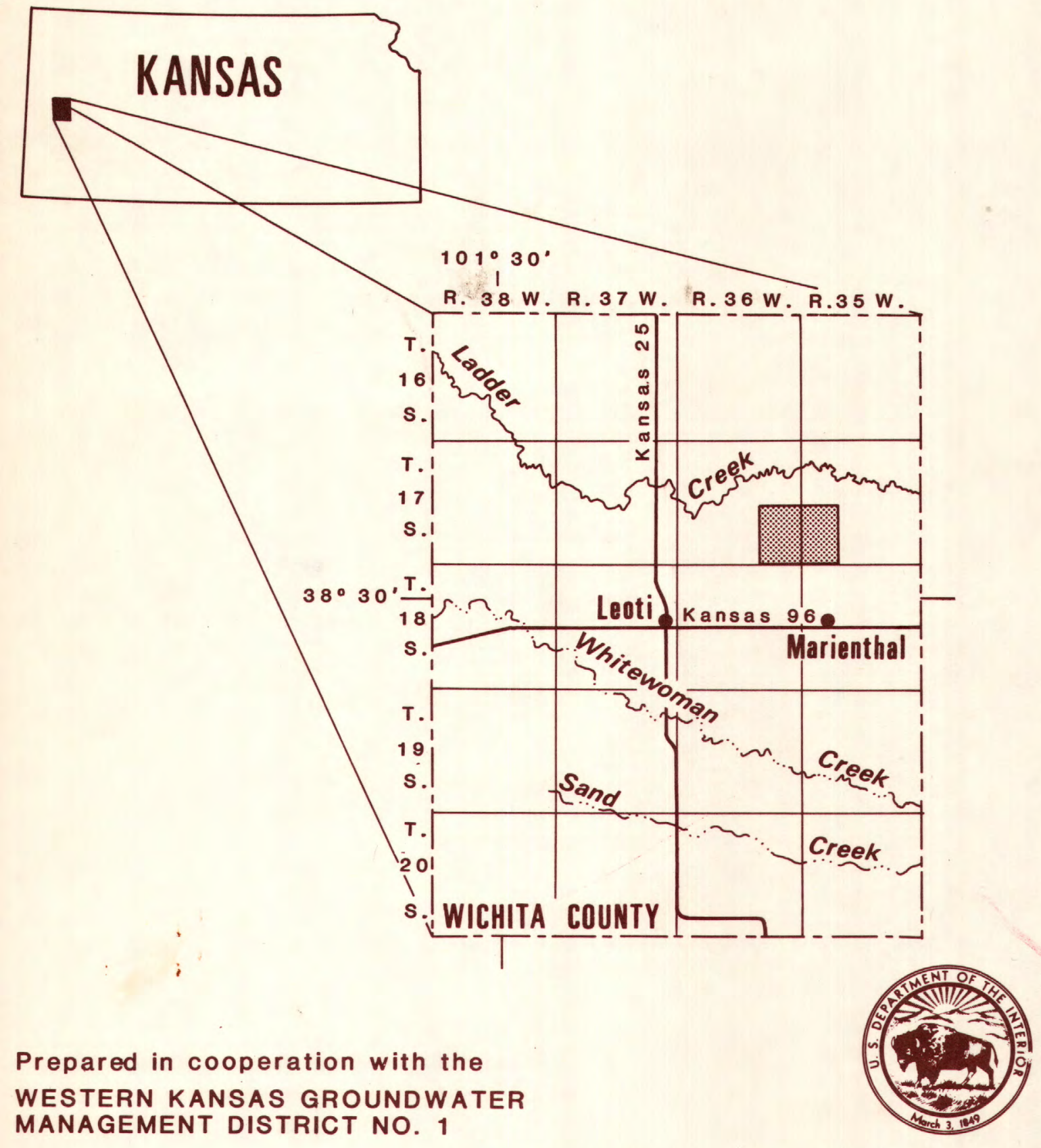


4. Title and Subtitle

GEOHYDROLOGY AND MODEL ANALYSIS FOR WATER-SUPPLY MANAGEMENT

IN A SMALL AREA OF WEST-CENTRAL KANSAS

5. Report Date

6. October 1980

7. Author(s)

Lloyd E. Dunlap, Jack Kume, and James G. Thomas

9. Performing Organization Name and Address

U.S. Geological Survey, Water Resources Division

1950 Avenue "A" - Campus West

Lawrence, Kansas 66045

12. Sponsoring Organization Name and Address

U.S. Geological Survey, Water Resources Division

1950 Avenue "A" - Campus West

Lawrence, Kansas 66045

15. Supplementary Notes

Prepared in cooperation with the Western Kansas Groundwater Management District No. 1.

16. Abstract (Limit: 200 words)

The saturated thickness of the Ogallala aquifer in an intensive-study area (12 square miles in northeastern Wichita County) has decreased substantially since the development of irrigation. Water levels have declined 1.08 to 2.22 feet per year during 1950-78.

During 1977, saturated thickness in the area ranged from 40 to 80 feet, aquifer storage was about 61,000 acre-feet, and natural recharge was estimated to be 0.28 inch per year. During 1977-78, irrigation wells pumped 7,400 acre-feet per year, and waterlevel declines ranged from 0.91 to 5.05 feet.

A ground-water flow model was used to predict the changes from 1978 to 1988 in the intensive-study area if pumpage in the model area was one-half, equal to, or double the 1977 rate. Water-level declines would range from 5 to 15 feet, 15 to 30 feet, and 25 to 40 feet, respectively. If pumpage in the intensive-study area is changed to one-half or double the 1977 rate, water-level declines would range from 10 to 20 feet or 20 to 25 feet, respectively.

17. Document Analysis a. Descriptors

Geohydrology, digital modeling, aquifer characteristics, natural recharge, irrigation pumpage, soil-zone modeling.

b. Identifiers/Open-Ended Terms

Ogallala aquifer, water-level declines, west-central Kansas.

c. COSATI Field/Group

18. Availability Statement

No restriction on distribution
19. Security Class (This Report) UNCLASSIFIED

20. Security Class (This Page) UNCLASSIFIED 
GEOHYDROLOGY AND MODEL ANALYSIS FOR WATER-SUPPLY

MANAGEMENT IN A SMALL AREA OF WEST-CENTRAL KANSAS

By Lloyd E. Dunlap, Jack Kume, and James G. Thomas

U.S. GEOLOGICAL SURVEY

Water-Resources Investigations 80-91

Prepared in cooperation with the WESTERN KANSAS GROUNDWATER MANAGEMENT DISTRICT NO. 1

Lawrence, Kansas

October 1980 


\section{UNITED STATES DEPARTMENT OF THE INTERIOR}

\section{CECIL D. ANDRUS, Secretary}

GEOLOGICAL SURVEY

H. William Menard, Director

For additional information write to:

District Chief

U.S. Geological Survey 1950 Avenue A - Campus West Lawrence, KS 66045 
Definition of terms - . . . . . . . . . . . 5

Abstract _. . . . . . . . . . . . . . . 7

Introduction _. . - . . . . . . . . . . . - 8

Purpose and scope - . - . . . . . . . . . . 8

Location of intensive-study area - . . . . . . . . - 8

Methods of investigation _ _ . - . - . . . . . - 11

Well-numbering system - - - - - - - - . - . - 11

Acknowl edgments _. . . . . . . . . . . . . 11

Conversion table - . - . . - . . . . . . . - 13

Geohydrology _. . . . . . . . . . . . . . . - 14

Unconsolidated aquifer in intensive-study area _ . . . - . - . 17

Occurrence and direction of ground-water movement _ - . - . - 17

Recharge - . . . . . . . . . . . . . . - 19

Discharge - . . . . . . . . . . . . . - 24

Aquifer characteristics - . - . - . . . . . - 25

Chemical quality of ground water - . . - . - . - . - 26

Irrigation efficiency - - - - - - - - - - - - - - 26

Soil-moisture monitoring - _ - . - . . - . . . - 27

Irrigation scheduling - - . - - - - - - - - - 30

Efficient pumping plants and wells _ - . . . . . . . 31

Water-supply management using a digital computer model- - . - . - . - 32

Mathematical model _ _ . . . . . . . . . . . . - 32

Steady-state model _ - _ . . - . . . . - . . 36

Transient-state model _ _ . . . . . . . . . . - 37

Pumpage - - . - - . - - . - . - - - - 37

Boundary conditions - - - - - - - - - - - 44

Calibration of transient model _ - . - . - . - - 49

Sensitivity analysis _ - . . . . . . - . - 49

Model projections of alternative plans - . - . - . - . - 52

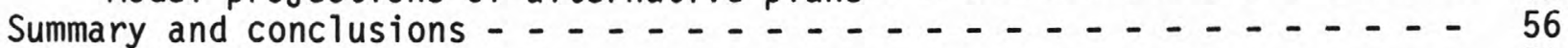

Selected references _ . . . . . . . . . . . . . . 58 


\section{ILLUSTRATIONS}

Figure

Page

1. Map showing location of intensive-study area - - - - - - - - - 9

2. Map showing location of collection sites for geohydrologic and climatic data _ _ _ $\ldots \ldots$. 10

3. Diagram showing wel1-numbering system _ $\ldots$

4. Generalized geologic cross sections of Ogallala Formation _ _ _ - 15

5. Map showing configuration of bedrock surface $\ldots \ldots$

6. Hydrograph of wel1 17-35W-30CBB _ - - - - - - $-\ldots$

7. Map showing altitude of water levels and direction of

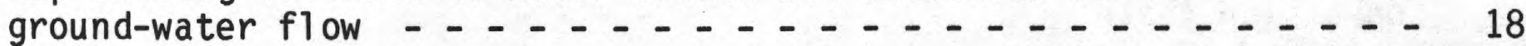

8. Map showing areas of equal saturated thickness, $1977 \ldots \ldots$

9. Map showing percentage decreases in saturated thickness,

1950-77, in unconsolidated aquifer _ _ _ _ _ _ _ _ _ _ $\ldots 21$

10. Map showing precipitation during growing season,

11. Graphs showing soil moisture and irrigation water applied

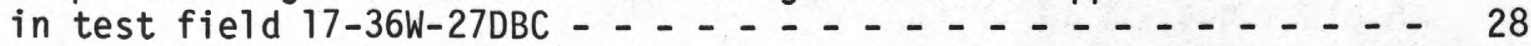

12. Map showing location of intensive-study area and model area

in Wichita and Scott Counties, Kans. _ _ _ _ $\ldots \ldots 33$

13. Map of model area showing finite-difference grid used

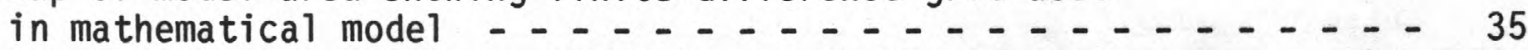

14. Map of model area showing hydraulic conductivity used

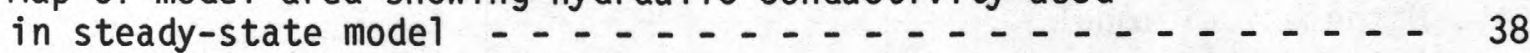

15. Map showing comparison of 1950-51 water-table contours from measurements and from steady-state model _ _ _ _ _ _ _ _ _ _ 39

16. Map of model area showing locations of irrigation wells in 1978 - $-\ldots+\ldots$ - $-\ldots$

17. Graph showing ground-water pumpage in model area based

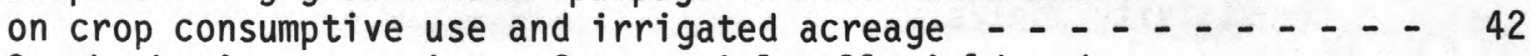

18. Graph showing comparison of potential well yield and saturated thickness with well-yield decrease _ _ _ - _ - _ _ - 44

19. Map showing the Ogallala aquifer west-central Kansas

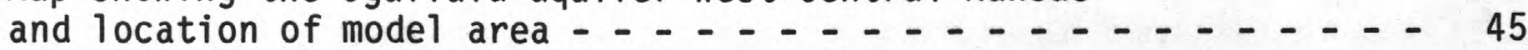

20. Map of model area showing boundary conditions during

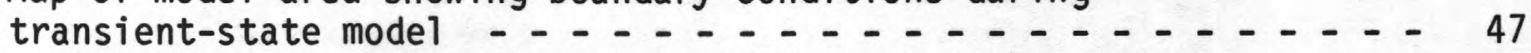

21. Map showing comparison of January 1978 water-table contours from measurements and from transient-state model _ _ _ _ _ _ _ _ 48

22. Graphs showing measured and computed water-level in selected wells - - _ - _ -

23. Sections through center of column 13 in model grid showing sensitivity of 1977 water levels to selected values for model parameters - _ - - - - - - - - - - - - - - - -

24. Maps showing simulated water-level declines in the intensive-study area resulting from selected pumpage rates in the model area - - - -

25. Graphs showing simulated water-level declines in three hypothetical wells in the intensive-study area resulting from different pumpage projections 
Aquifer - Formation, group of formations, or part of a formation that contains sufficient saturated permeable material to yield significant quantities of water to wells and springs.

Available soil moisture - the quantity of water in soil that is available to plants.

Confined aquifer - Aquifer in which an artesian water body exists. The water level in a well completed in the aquifer stands above the top of the artesian water body.

Constant-flux boundary - A model boundary condition that has a fixed value of volumetric flow rate per unit area (discharge) across the boundary.

Constant-gradient boundary - A model boundary condition that changes flow rate across the boundary as saturated thickness changes. The hydraulic gradient across the boundary remains constant with changes in saturated thickness.

Constant-head boundary - A model boundary condition that has a fixed value of static head, which is the height above a standard datum of the surface of a column of water that can be supported by the static pressure at a given point.

Digital model - A simplified mathematical representation of a complex system. A computer program to solve ground-water flow equations.

Discharge - Flow of water expressed as a volume per unit of time.

Ephemeral stream - A stream that flows briefly only in direct response to precipitation in the immediate locality and has a channel that is, at all times, above the water table.

Evapotranspiration - Volume of water lost through transpiration of plants and evaporation from the soil.

Geophysical log - A record obtained by lowering an instrument into a borehole or well and recording continuously on a meter at the surface some physical properties of the rock material being logged.

Hydraulic conductivity - Volume of water a medium will transmit in unit time at the prevailing viscosity through a cross section of unit area, measured at right angles to the direction of $\mathrm{flow}$, under a hydraulic gradient of unit change in head through a unit length of flow.

Hydraulic gradient - Rate of change of hydraulic head per unit of distance of flow at a given point and in a given direction.

Hydraulic head - Height of the free surface of a body of water above a given subsurface point. 
Perennial stream - A stream that flows throughout the year.

Potentiometric surface - A surface representing the hydrostatic head. In an unconfined aquifer, the surface coincides with the water table. In a confined aquifer, the surface is defined by the levels to which water stands in tightly cased wells above the water body in the aquifer.

Power factor - Energy consumed to pump 1 acre-foot of water.

Recharge - Amount of water added to the zone of saturation.

Saturated thickness - Amount of water-bearing material filled with water under pressure greater than atmospheric.

Semiconfined aquifer - Aquifer in which a semiartesian water body exists. Confining beds leak water either from or to the aquifer.

Solar radiation - Amount of solar radiant energy received, as expressed in langley units (calories of energy per square centimeter).

Specific capacity - Rate of discharge of water from a well divided by the drawdown of water in the well. If constant except for the time variation, it is approximately proportional to the transmissivity of the aquifer.

Specific conductance - Conductance, the ability of a substance to conduct an electric current, of a body of unit length and unit cross section at a specified temperature.

Specific yield - Ratio of the volume of water that the material after being saturated will yield by gravity to the volume of the material.

Steady-state - Equilibrium water levels or heads; water levels do not vary significantly with time.

Storage coefficient - Volume of water an aquifer releases from or takes into storage per unit surface area of the aquifer per unit change in head.

Transient state - Nonequilibrium water levels or heads; water levels do vary significantly with time.

Transmissivity - Rate at which water of the prevailing kinematic viscosity is transmitted through a unit width of an aquifer under a unit hydraulic gradient.

Unconfined aquifer - Aquifer in which a water-table body exists.

Water table - Surface in an unconfined water body at which the pressure is atmospheric. It is defined by the levels at which water stands in wells that penetrate the water body just far enough to hold standing water. 
GEOHYDROLOGY AND MODEL ANALYSIS FOR WATER-SUPPLY

MANAGEMENT IN A SMALL AREA OF WEST-CENTRAL KANSAS

Lloyd E. Dunlap*, Jack Kume*, and James G. Thomas**

\section{ABSTRACT}

The Ogallala Formation in the intensive-study area, an area of 12 square miles in northeastern Wichita County, west-central Kansas, has had a substantial decrease in saturated thickness since the development of irrigation. The annual water-level decline during 1950-78 ranged from 1.08 to 2.22 feet per year.

The hydrologic system was investigated to study methods of conserving the remaining ground water in the intensive-study area. During 1977-78, the average annual ground-water withdrawal was 7,400 acre-feet, and the water-level decline ranged from 0.91 to 5.05 feet. The saturated thickness in 1977 ranged from about 40 to 80 feet, and aquifer storage was about 61,000 acre-feet. Natural recharge is estimated to be 0.28 inch per year.

Projections from a digital ground-water flow model were used to indicate the additional water-level decline that might occur from 1978 to 1988 if pumpages in the 480-square-mile model area were one-half, equal to, or double the 1977 pumpage rate. The additional water-level declines in the intensivestudy area would range from 5 to 15 feet if pumpages were one-half, 15 to 30 feet if pumpages were equal to, and 25 to 40 feet if pumpages were double the 1977 rate. Projections also were used to indicate the water-level declines if pumpages in the model area were equal to the 1977 rate and if pumpages in the intensive-study area were one-half or double the 1977 rate. Additional water-level declines in the intensive-study area would range from 10 to 20 feet if pumpages were one-half and from 20 to 25 feet if pumpages were doubled. Decreased pumpage in the area could reduce the water-level declines, but continued pumpage in adjacent areas would cause declines to be greater near the edge than near the center.

The digital model was more sensitive to changes in pumpage than to changes in hydraulic conductivity, specific yield, and recharge.

* U.S. Geological Survey, Garden City, Kansas

** Kansas State Extension, Garden City, Kansas 
Purpose and Scope

Ground-water withdrawals for irrigation in west-central Kansas are gradually depleting the amount of water stored in the 0gallala Formation. Because the economy largely depends on the continued production of food and fiber through irrigation, the continued availability of ground water is of immediate concern to State and local water-planning agencies.

The Western Kansas Ground-water Management District No. 1, located in westcentral Kansas, recognizes that conservation of ground water through efficient use is the most practical means for prolonging the availability of ground water for irrigation. Local irrigators are being encouraged to participate in a district-wide conservation program in which crop yields may be maintained or improved by efficient water use and timely irrigations. Savings in energy costs may be realized by using efficient pumping plants and properly constructed wells and by reducing the amount of ground water pumped.

A study was conducted in a selected area of western Kansas by the U.S. Geological Survey, in cooperation with the Western Kansas Groundwater Management District No. 1, to evaluate methods for conserving the ground-water resources. The purpose of the study was: (1) To provide a detailed description of geohydrologic conditions, (2) to determine the annual ground-water withdrawal, (3) to determine the changes in water levels and saturated thicknesses from 1950 to 1979, (4) to investigate ways of minimizing ground-water depletions through improved irrigation techniques, (5) to develop a digital model of the area to simulate hydrologic conditions in the aquifer, and (6) to project water-level changes for various management plans.

The scope of the study was limited to a sample area that was small enough for intensive study and that represented areas where severe declines in saturated thickness have occurred. In west-central Kansas, the percentage change in saturated thickness of the unconsolidated aquifer for 1950-77 in Greeley, Lane, Scott, Wallace, and Wichita Counties ranged from less than 10 percent to greater than 50 percent. Wichita County contained the most area having percentage changes greater than 50 percent. Therefore, an area of 12 square miles in Wichita County was chosen for intensive study.

\section{Location of Intensive-Study Area}

The intensive study of geohydrologic and related information was made in a 12-square-mile area located about 3 miles north of Marienthal in Wichita County, west-central Kansas (fig. 1). This area includes secs. 23, 24, 25, 26,35 , and 36 in T.17 S., R.36 W. and secs. 19, 20, 29, 30, 31, and 32 in T.17 S., R.35 W. 


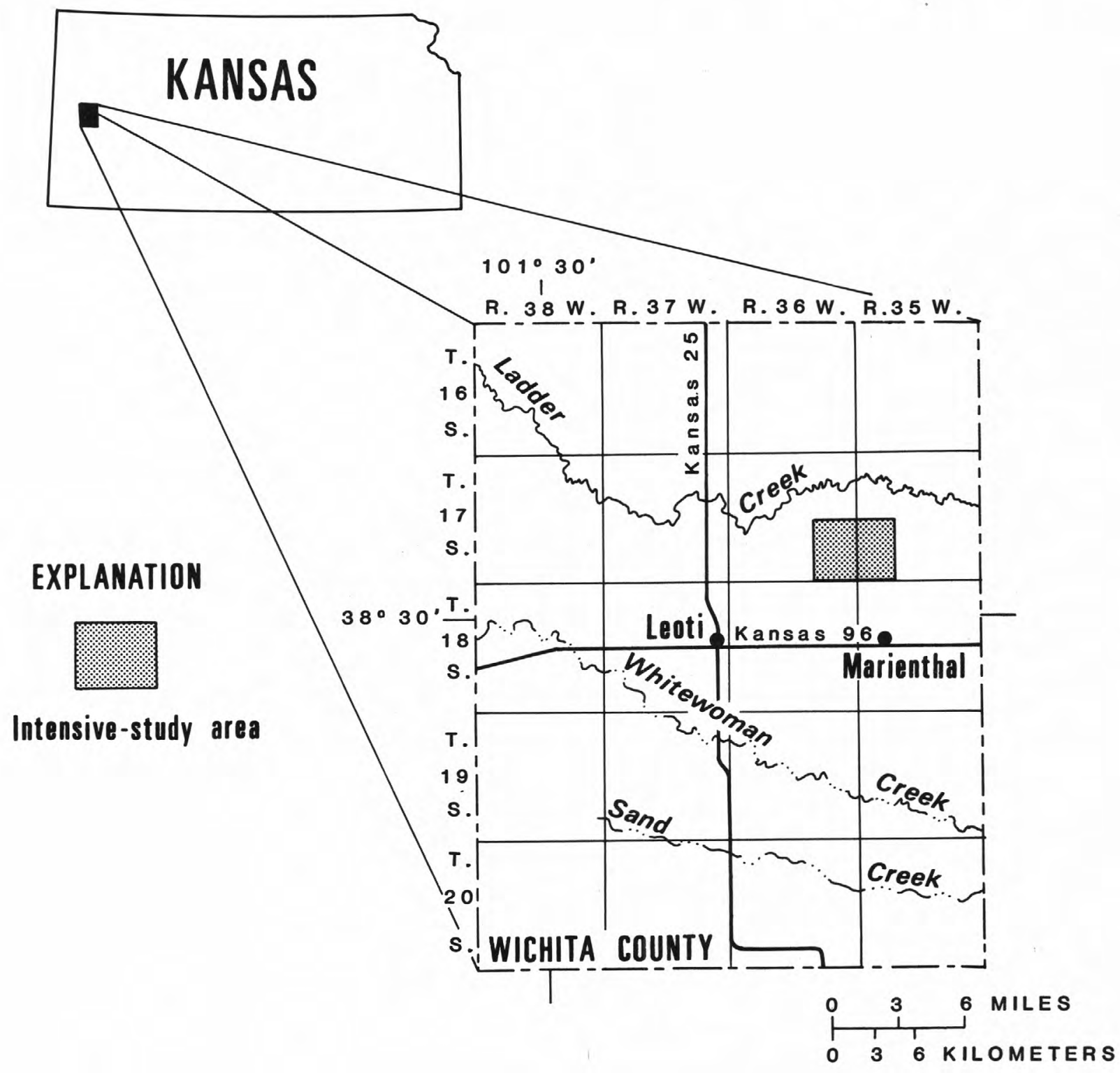

Figure 1.--Location of intensive-study area. 


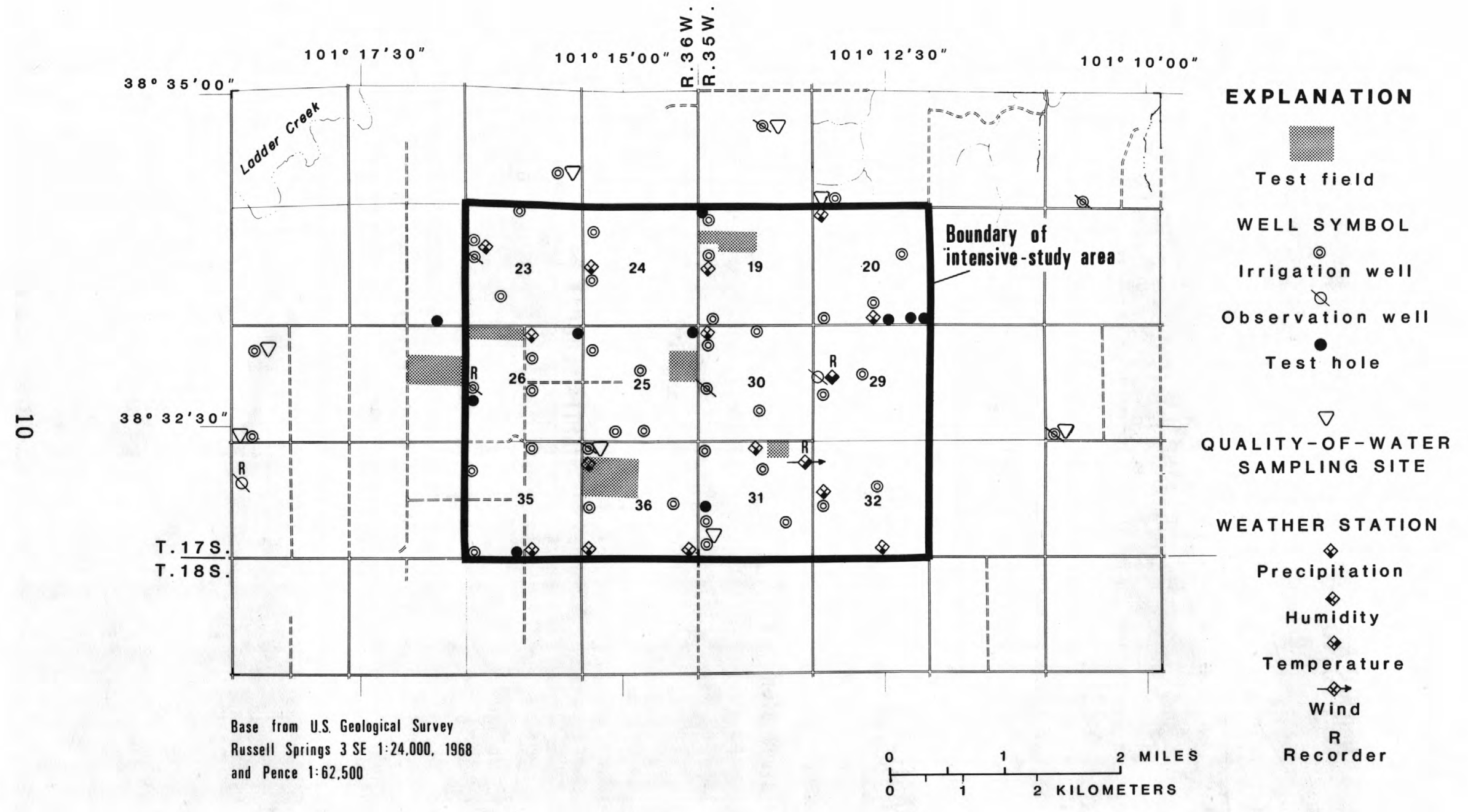

Figure 2.--Location of collection sites for geohydrologic and climatic data. 
Data collection began during the summer of 1976 and was completed during the winter of 1978-79. The data included: (1) Instantaneous and accumulated discharges of irrigation wells, the rate and accumulated power consumption of pumping plants, and accumulated well-production time of 33 hour-metered wells; (2) physical and hydrologic properties of the unconsolidated aquifer, including its lithology, thickness, areal extent, saturation, and water movement; (3) weather data, including precipitation, rate and direction of wind, temperature, and relative humidity; (4) soil-moisture data; (5) solar radiation; (6) crop acreage and yield; and (7) periodic measurement of water levels. Other activities included test drilling by the Kansas Geological Survey, geophysical logging, and constructing observation wells. Data from previous reports and from the files of the U.S. Geological Survey and the Division of Water Resources, Kansas State Board of Agriculture, were compiled and analyzed. The locations of the collection sites for geohydrologic and climatic data are shown in figure 2.

A digital ground-water model was constructed to simulate the response to the Ogallala aquifer to existing conditions. The model was then used to test different management alternatives by simulating future water-level trends with changes in pumpage.

\section{We11-Numbering System}

The well-numbering system, as shown in figure 3 , gives the location of the well or test hole according to the U.S. Bureau of Land Management's system of land subdivision. In this system, the first set of digits of a well number indicates the township; the second set, the range east or west of the Sixth Principal Meridian; and the third set, the section. The first letter after the section number denotes the 160-acre tract; the second, the 40-acre tract; and the third, the 10-acre tract. Where two or more wells are located in a 10-acre tract, consecutive numbers are added in the order in which the wells were inventoried. Thus, in Wichita County, the number 17-35W-18ACB indicates that the well is in the NW1/4SW1/4NE1/4 sec. 18, T.17 S., R.35 W.

\section{Acknowledgments}

Appreciation and thanks are expressed to many Wichita County residents and individual water users in and near the project area who permitted access to their property and supplied information about their wells, amount of pumpage, and crop yield and acreage. 


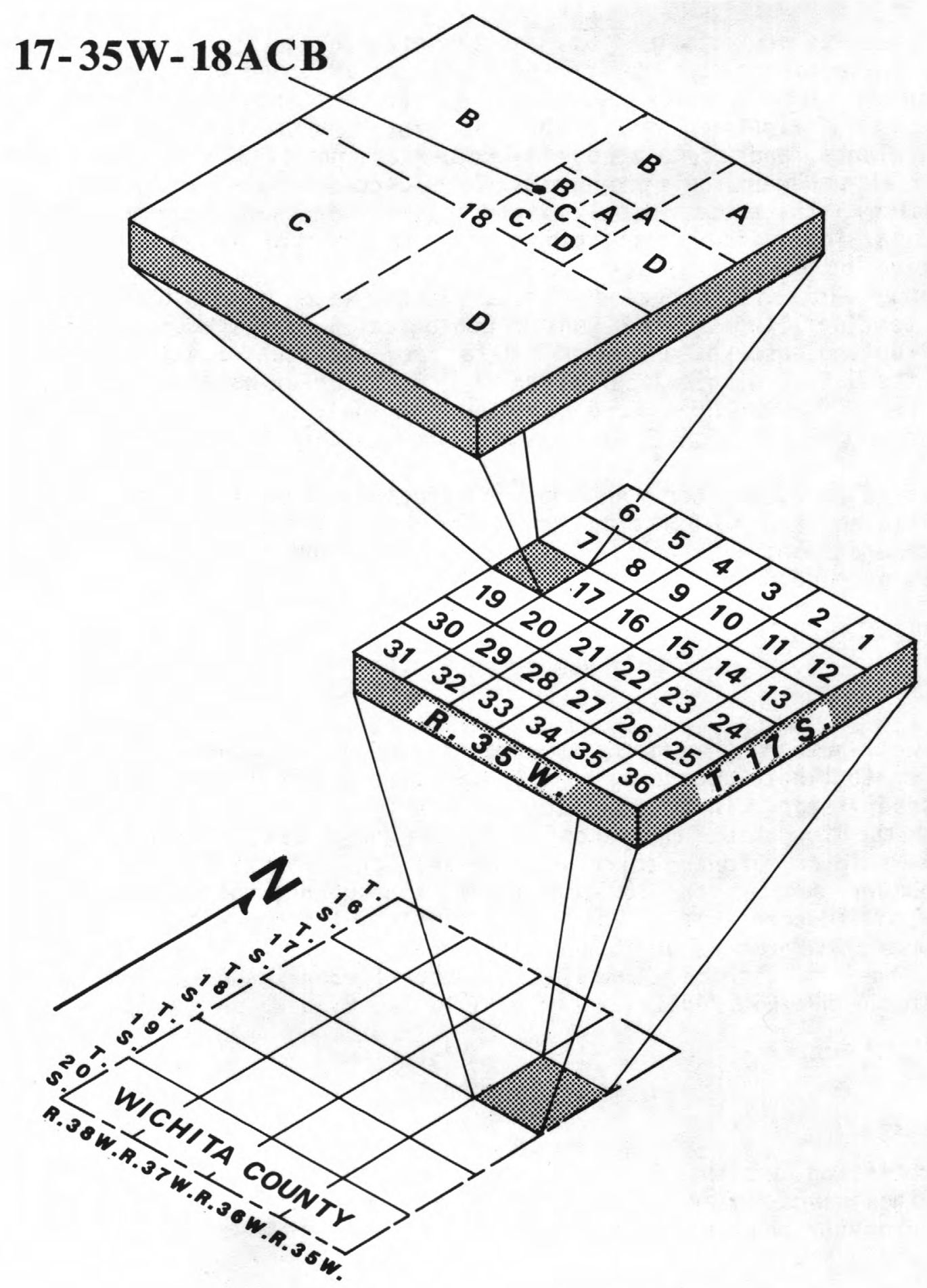

Figure 3.--Well-numbering system. 
For readers preferring to use metric units rather than inch-pound units, the conversion factors for the International System (SI) of Units and abbreviations for terms are listed below:

To convert from inch-pound units

Length

inch (in)

foot $(\mathrm{ft})$

mile (mi)
To SI

units
Multiply by

25.4

millimeter

meter

0.3048

1.609

Area

acre

square mile $\left(m i^{2}\right)$ square meter

square kilometer
4,047

2.590

Volume

$\begin{array}{ll}\text { gallon (gal) } & \text { liter } \\ \text { bushel (bu) } & \text { liter } \\ \text { cubic foot }\left(\mathrm{ft}^{3}\right) & \text { cubic meter } \\ \text { acre-foot (acre-ft) } & \text { cubic meter }\end{array}$

Flow

foot per day $(f t / d)$

foot squared per day $\left(\mathrm{ft}^{2} / \mathrm{d}\right)$

gallon per minute

(gal/min)

gallon per minute per

foot $[(\mathrm{gal} / \mathrm{min}) / \mathrm{ft}]$ meter per day

meter squared per day

liter per second

liter per second per meter
0.3048

0.0929

0.06309

0.2070

Pressure

bar

kilopascal

100

Temperature

degree Fahrenheit $\left({ }^{\circ} \mathrm{F}\right)$

degree Celsius

1/

1) ${ }^{\circ} \mathrm{C}=\left({ }^{\circ} \mathrm{F}-32\right) / 1.8$.

Note: Datum used in this report is National Geodetic Vertical Datum (NGVD) of 1929, formerly called mean sea level datum. 
The land surface in the study area is a flat upland that is part of the High Plains of western Kansas. Drainage is mostly by tributaries of Ladder Creek on the north and Whitewoman Creek on the south. These ephemeral streams are not reliable sources of water.

Loess of Pleistocene age underlies the surface to depths ranging from 20 to 50 feet. These deposits consist chiefly of windblown silt interbedded with thin layers of clay and fine sand. The loess occurs above the water table in the major aquifer and is not saturated.

The Ogallala Formation of Miocene age consists of interbedded clay, silt, sand, gravel, and caliche, with calcium-carbonate-cemented sand (mortar beds). In the intensive-study area, these deposits range in thickness from about 150 to 200 feet. Generalized geologic cross sections of the 0gallala Formation in the study area show the heterogeneity of the deposits (fig. 4). The individual beds of silt, clay, sand, gravel, or caliche can be correlated with confidence only short distances away from known test holes (Kume and others, 1979, p. 12-23). The aquifer in the lower part of this formation, which yields as much as $1,500 \mathrm{gal} / \mathrm{min}$ to wells, is the principal source of water in this area.

The Niobrara Chalk of Late Cretaceous age directly underlies the Ogallala Formation. The upper part, the Smoky Hill Member, consists of yellow to orangeyellow chalk and light- to dark-gray beds of chalky shale that locally weather to ochre-yellow. A map of the configuration of the bedrock surface in the intensive-study area shows two shall ow buried valleys (fig. 5). The bedrock surface, which ranges in altitude from about 2,990 to 3,060 feet, slopes from the west and southwest toward the east.

Upper Cretaceous rocks underlying the area consist mostly of chalky shale, shale, and limestone that are not known to yield significant amounts of water to wells. Aquifers in Lower Cretaceous rocks, principally the Dakota Formation and Cheyenne Sandstone, generally do not yield water of adequate quantity or quality for irrigation supplies. For additional information on Cretaceous rocks, see Slagle and Weakly (1976) and others listed in the "Selected References." 

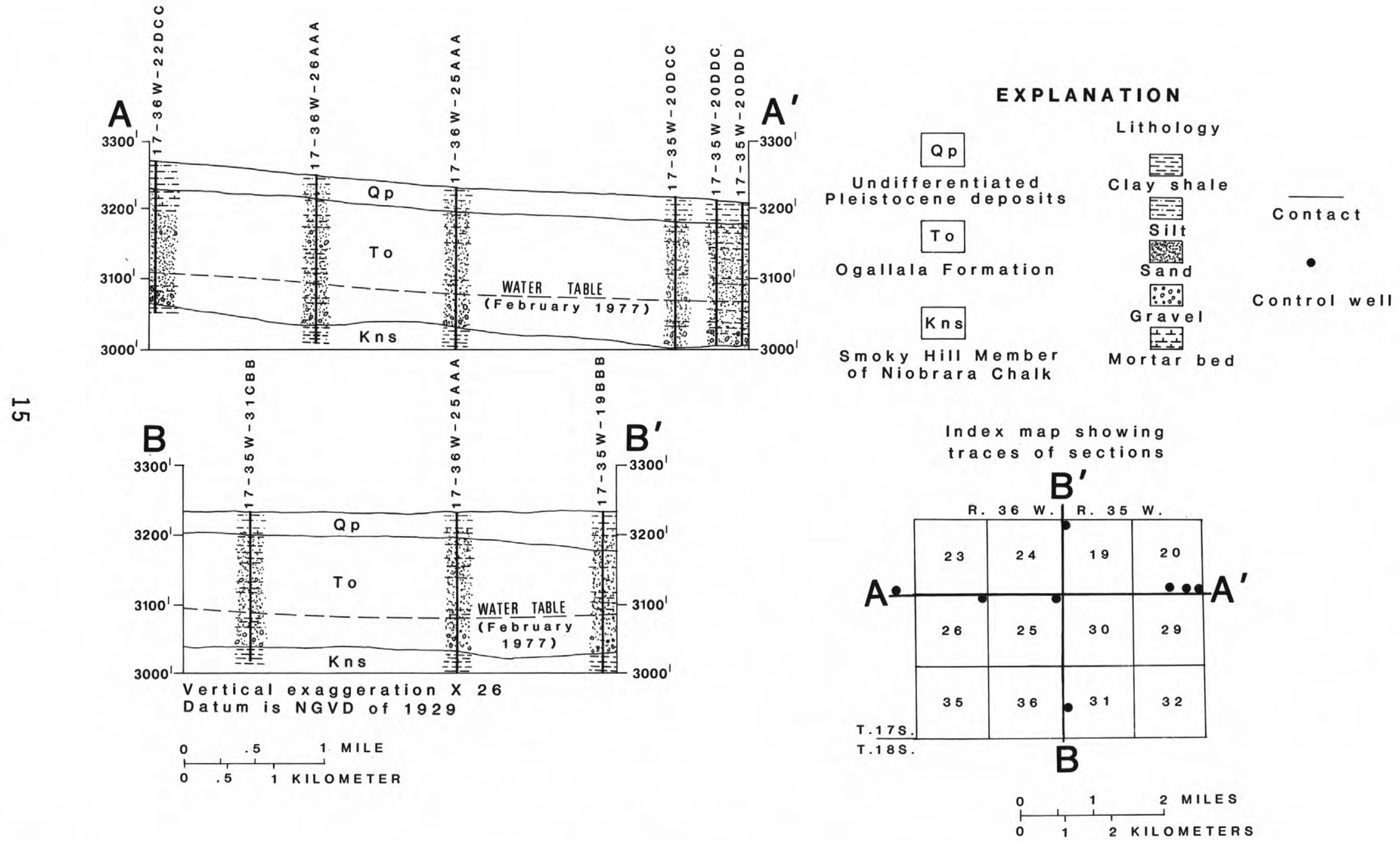

Figure 4.--Generalized geologic cross sections of Ogallala Formation (from Johnson, 1978). 


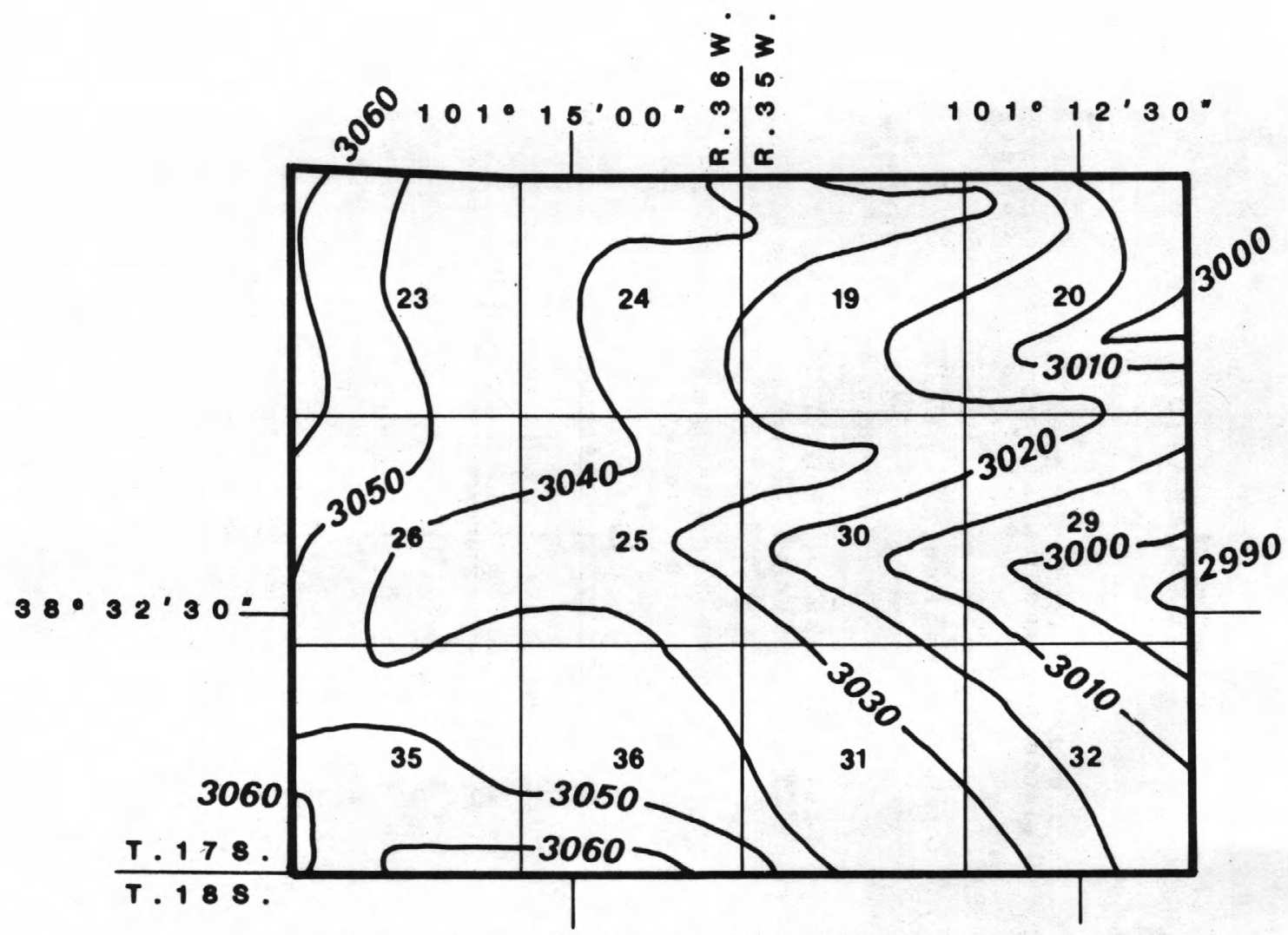

EXPLANATION

Bedrock contour

Show altitude of bedrock surface (Niobrara Chalk). Contour interval 10 feet. Datum is NGVD of 1929

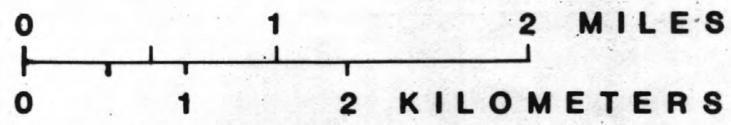

Figure 5.--Configuration of bedrock surface. 
Occurrence and Direction of Ground-Water Movement

The unconsolidated aquifer includes the saturated part of the unconsolidated deposits and, in this area, is entirely within the 0gallala Formation. This aquifer underlies the entire intensive-study area.

Depth to water in wells during January 1978 ranged from about 130 to 160 feet below the land surface. The annual water-level decline during 1977-78 ranged from a 0.91 to 5.05 feet and averaged 2.19 feet.

Water-level declines from 1950 to 1978 ranged from 30.10 to 62.24 feet and average 47.84 feet. The annual water-level decline during 1950-78 ranged from 1.08 to $2.22 \mathrm{ft} / \mathrm{yr}$ and averaged $1.71 \mathrm{ft} / \mathrm{yr}$ (Kume and others, 1979, p. 26-35).

An example of the steady decline in water levels is reflected in a hydrograph of irrigation well 17-35W-30CBB (fig. 6). Fluctuations each year reflect the water-level decline from pumping during the summer and the water-level rise from recovery during the winter.

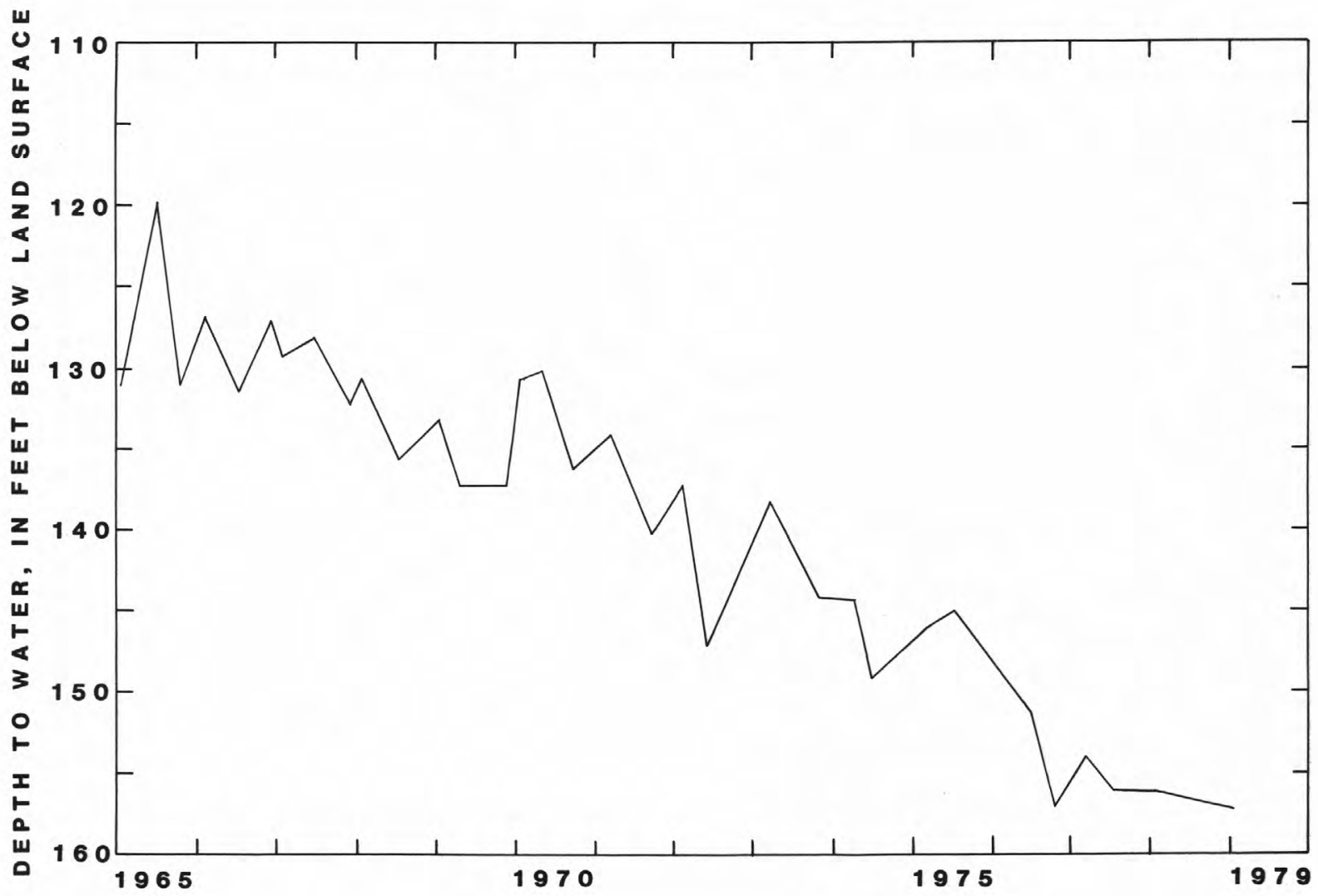

Figure 6.--Hydrograph of well 17-35W-30CBB. 


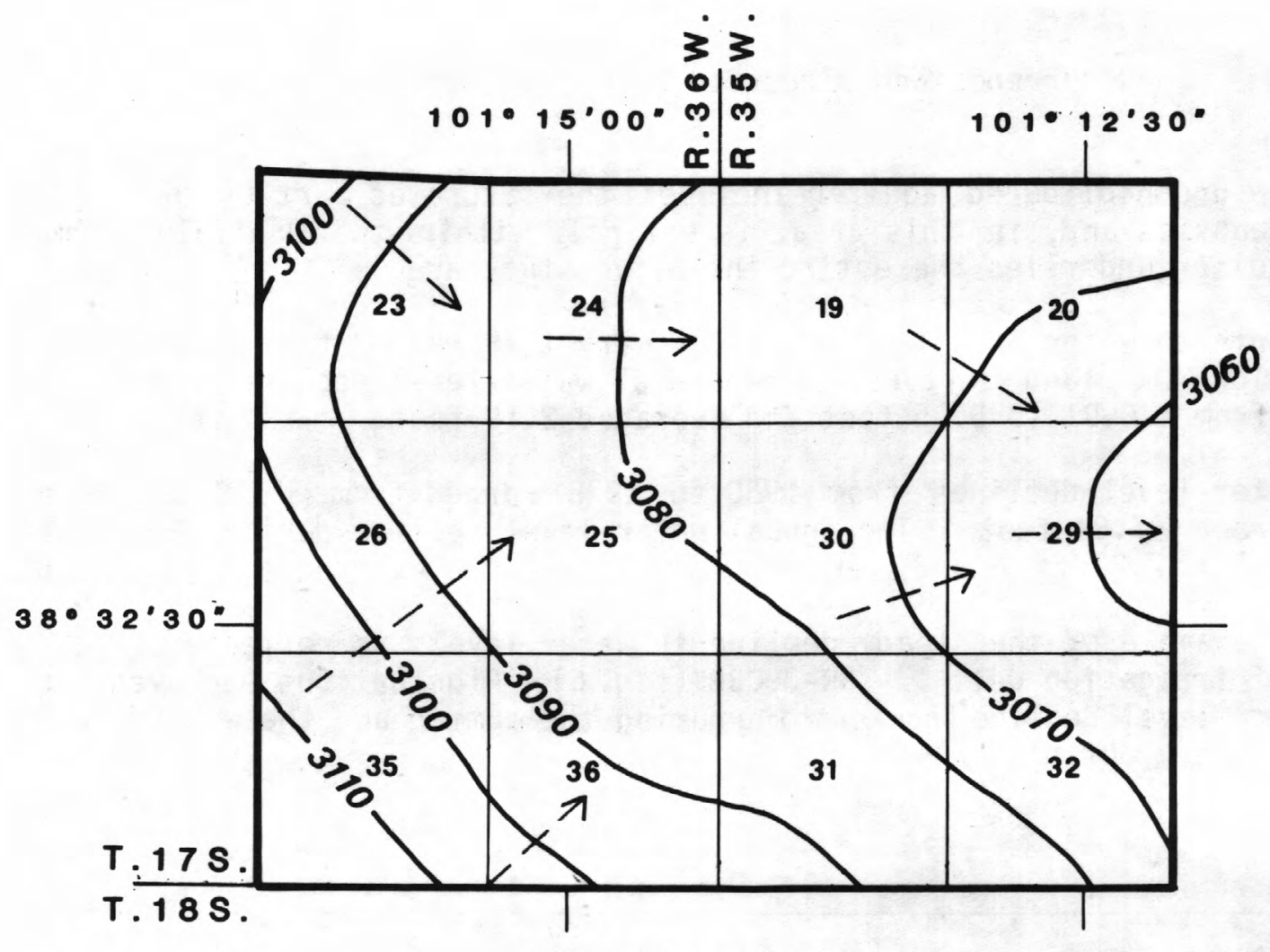

EXPLANATION

\section{$3080-$}

Water-table contour

Shows altitude of water table, June 1977. Contour interval 10 feet. Datum is NGVD of 1929

$$
\text { Flow direction }
$$

Arrow points in the direction of groundwater flow

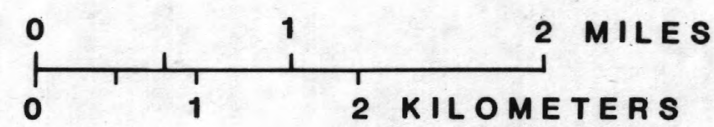

Figure 7.--Altitude of water levels and direction of ground-water flow. 
The ground-water flow is reflected in the water-table configuration in June 1977, after preirrigation and early irrigation-season pumping (fig. 7). Flow from the southwest and northwest moves toward the center of the intensivestudy area and then moves eastward. The altitude of the water table during 1977 ranged from about 3,060 to 3,120 feet in a distance of 4 miles for a southwest to east hydraulic gradient of 0.0028 . Variations in the hydraulic gradient in the study area ranged from 0.0019 to 0.0043 .

The thickness of the saturated material in the unconsolidated aquifer during 1977 ranged from about 40 to 80 feet (fig. 8 ). The average saturated thickness measured in seven irrigation wells decreased from 115 feet in 1950 to 67 feet in 1978 (Kume and others, 1979, p. 35). Percentage decreases in saturated thickness in the intensive-study area during 1950-77 are shown in figure 9. The percentage decrease in saturated thickness in terms of the area in the project $(1950-77)$ is shown by the following table:

Percentage decrease in saturated thickness

Intensive-study area

Square Percent

miles

$\begin{array}{lll}30 \text { to } 40 & 4.2 & 35 \\ 40 \text { to } 50 & 6.6 & 55 \\ 50 \text { to } 60 & \underline{1.2} & 10 \\ \text { TOTAL } & 12.0 & 100\end{array}$

Recharge

The Ogallala Formation in west-central Kansas is recharged naturally by infiltration from precipitation and ephemeral streams that dissect the area.

Precipitation on the land surface is the main source of recharge to the area. Based on records of the National Weather Service (1941-70), the average annual precipitation is estimated to be about 19 inches. The resulting recharge to the aquifer, as cited in literature pertaining to western Kansas, commonly ranges from 1 to 10 percent of the annual precipitation (120 to 1,200 acre-ft) in the intensive-study area (Gutentag and Stullken, 1976, p. 11) 


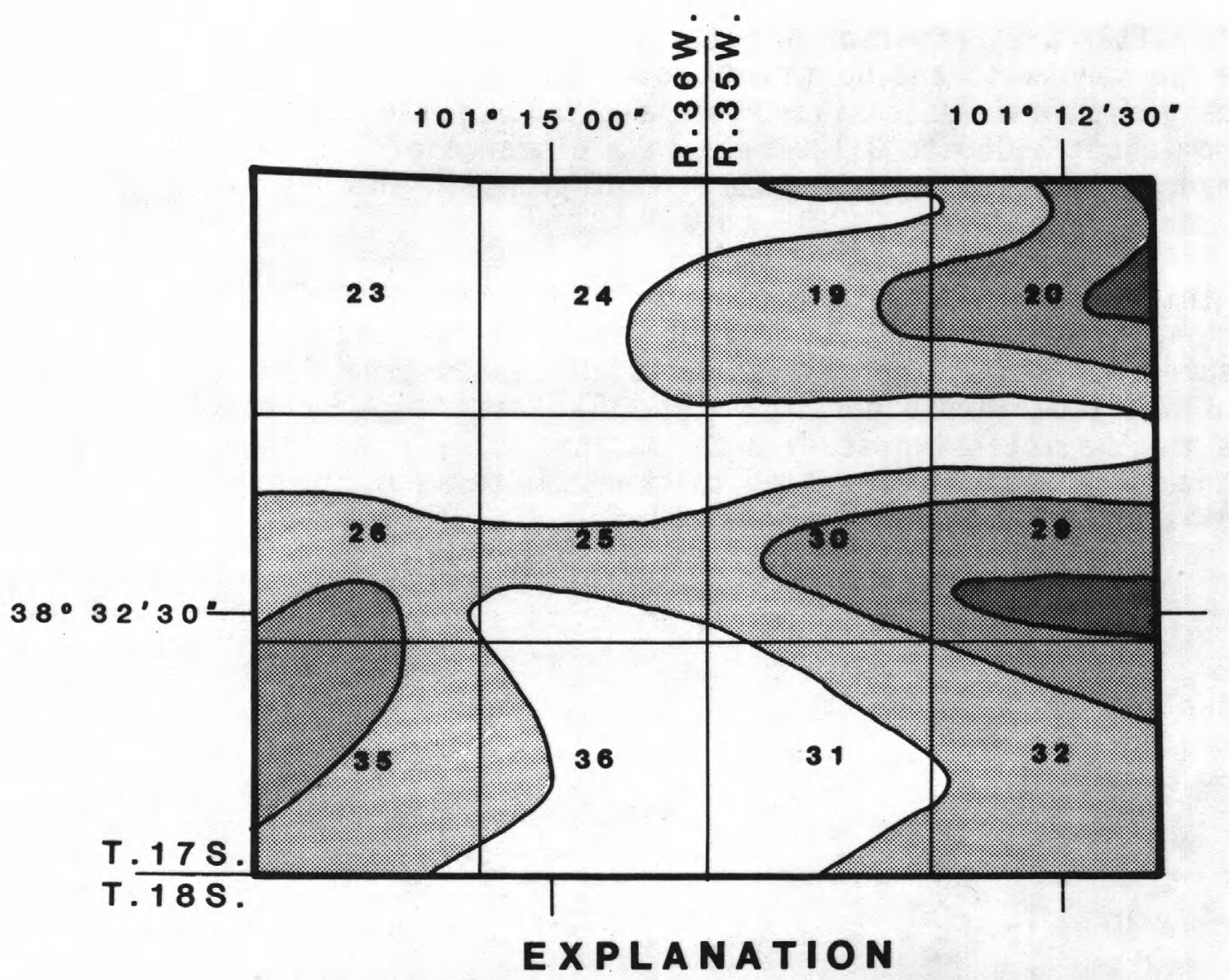

Area of equal saturated thickness during 1977 , in feet
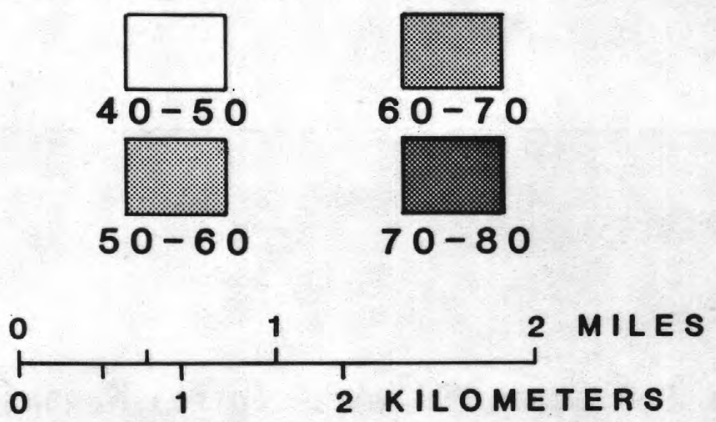

Figure 8.--Areas of equal saturated thickness, 1977. 


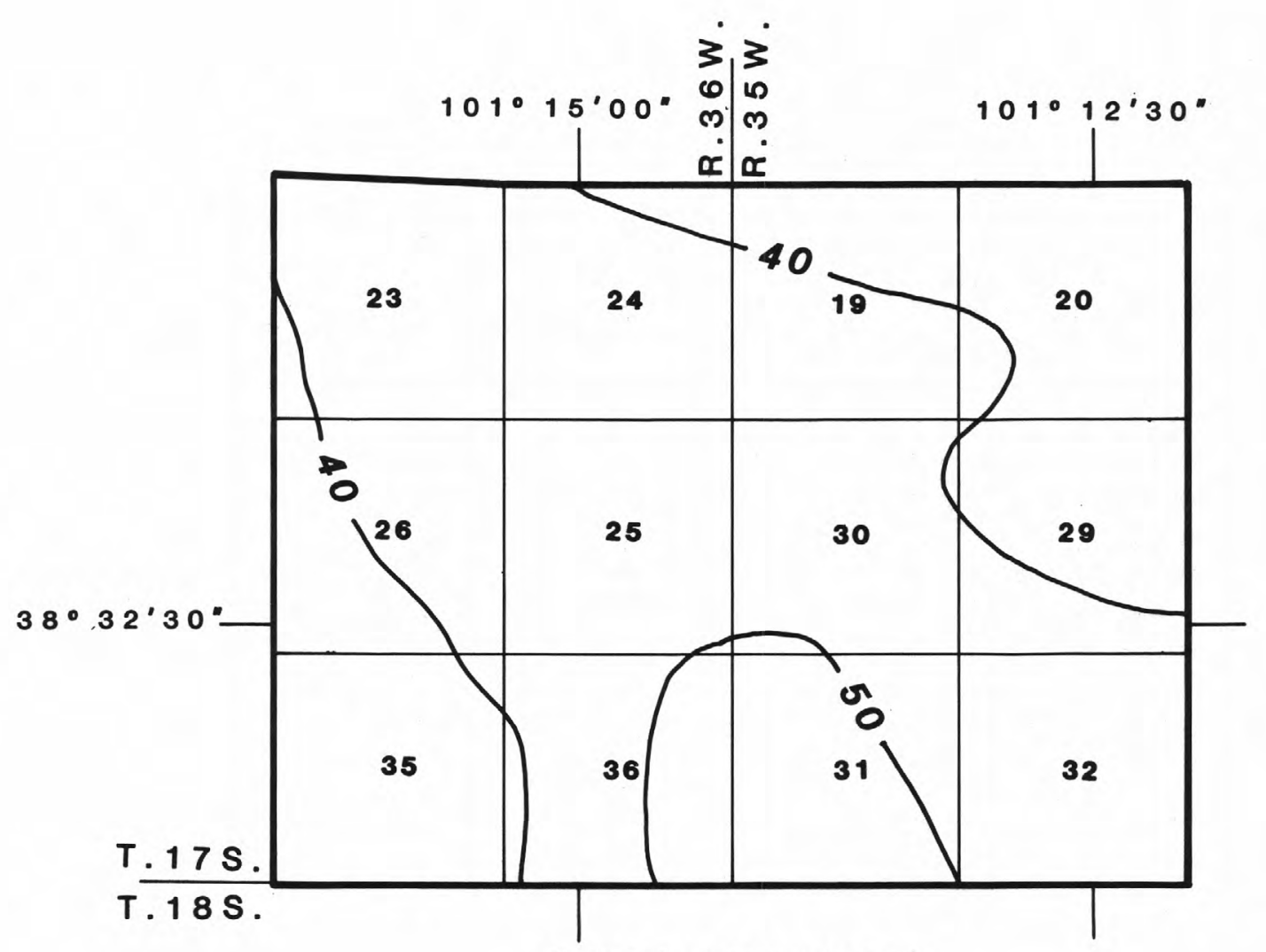

EXPLANATION

$$
50
$$

Line of equal percentage decrease in saturated thickness

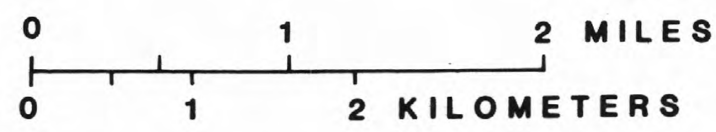

Figure 9.--Percentage decreases in saturated thickness, 1950-77, in unconsolidated aquifer. 
Most of the precipitation occurs during the June-September growing season. Data from 16 rain gages in the study area were used to show the distribution of rainfall during June-September 1977 (fig. 10). Using the Thiessen polygon method, the average precipitation was calculated to be 11.76 inches. Variations rainfall during are caused by localized storm cells instead of general rains. During 1977, the rainfall on test fields averaged about 3 inches, or 40 percent, more than the 51-year average rainfall for the same period of time at Garden City, about 40 miles southeast in Finney County, and at Tribune, about 30 miles west in Greeley County, Kansas. The same comparison for 1978 showed that the rainfall on these test fields averaged about 4 inches, or 56 percent, less than the 51-year average at Garden City and Tribune (Kume and others, 1979, p. $36-37)$.

Prior to the development of ground-water irrigation during the 1950's, Ladder Creek was a perennial stream and was a major source of recharge to the aquifer in the study area. As increasingly large quantities of water were pumped from the aquifer in west-central Kansas, ground-water inflow to streams ceased in most of the area. Thus, streamflow in Ladder Creek became a source of recharge to the Ogallala Formation only during floods when water infiltrated through the streambed into the aquifer. No information on Ladder Creek is available regarding the frequency of floods and the amount of water recharged through the streambed.

Very little surface-water runoff comes into or leaves the study area because the drainage is so poorly developed. The nearly level land surface slopes gently to the east. North and south of the area, Ladder and Whitewoman Creeks capture the runoff from the area. Although the amount of direct runoff is unknown, it probably ranges from 0.25 to 0.5 inch (McGuinness, 1964). No rainfall runoff or irrigation runoff leaving or entering the area was observed during this study.

Streamflow in Ladder Creek during 1951 was reported by Bradley and Johnson (1957, p. 49) to have contributed 0.82 inch of direct runoff in response to 26.90 inches of precipitation. An assumed annual runoff of approximately 0.3 inch would amount to about 200 acre-ft/yr. Surface water generally is lost to infiltration and deep percolation after it travels relatively short distances over a permeable land surface.

Subsurface ground-water inflow occurs along the north, west, and south boundaries of the intensive-study area. Using a total saturated cross-sectional area of about 2.46 million $\mathrm{ft}^{2}$, hydraulic gradients ranging from 0.0019 to 0.0043 , and a hydraulic conductivity of $75 \mathrm{ft} / \mathrm{d}$, the subsurface inflow was calculated to be about 4,700 acre-ft/yr during 1978 .

Assuming that 5 percent of the applied irrigation water $(7,400$ acre-ft) percolates below the root zone and eventually reaches the water table, approximately 400 acre-ft/yr are returned to aquifer. Deep percolation probably occurs mostly during preirrigation and times of above-normal precipitation. 


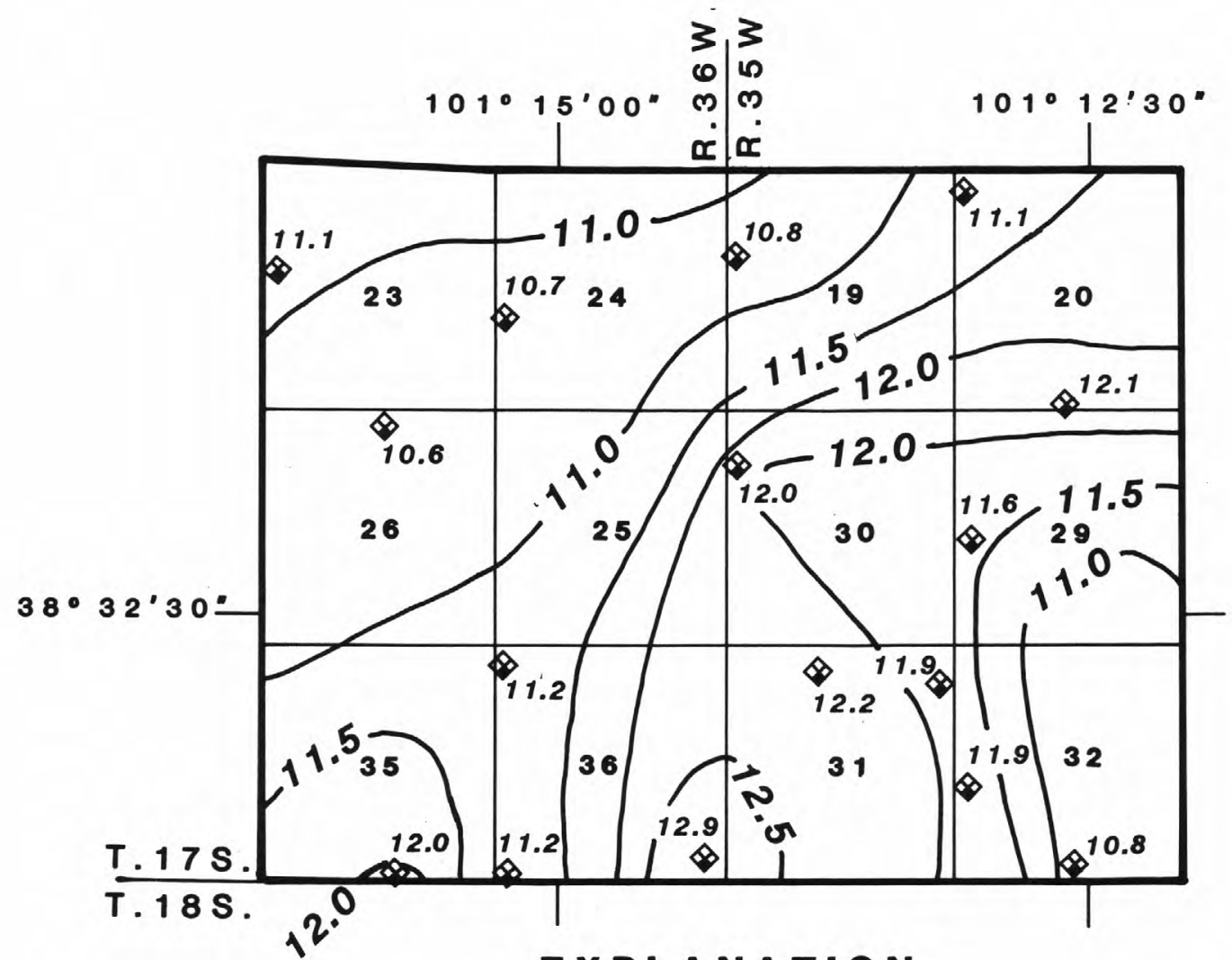

EXPLA NATION

11.5

Line of equal rainfall

Interval 0.5 inch

Precipitation station

Number is the amount of precipitation during June - September 1977, in inches

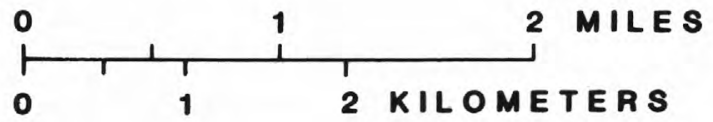

Figure 10.--Precipitation during growing season, June-September 1977. 


\section{Discharge}

Ladder Creek was a perennial stream in the model area during the 1950's, and inflow to the stream was a major discharge for the Ogallala Formation. No streamflow data in this area exists on Ladder Creek during this time.

Subsurface ground-water outflow occurs along the east boundary of the intensive-study area. Assuming a cross-sectional area of saturated thickness of about $685,000 \mathrm{ft}^{2}$, hydraulic gradients ranging from 0.0028 and 0.0043 , and a hydraulic conductivity of $75 \mathrm{ft} / \mathrm{d}$, the subsurface outflow was calculated to be about 1,600 acre-ft/yr during 1978.

The water lost to the atmosphere from precipitation on the 1 and area through evaporation from the soil and transpiration of plants is estimated to be about 11,600 acre-ft/yr. This is the amount of water remaining after other water budget items are considered. Because the water table is more than 125 feet below the land surface, evapotranspiration from the aquifer probably does not exist.

As a result of the increased irrigation development, the major source of ground-water discharge is through irrigation wells. To determine the amount of water pumped, 36 recording water meters were installed during late spring 1977 to measure well discharges (Kume and others, 1979, p. 43-45). These meters showed the rate of discharge in gallons per minute and recorded the accumulated discharge in acre-feet. Two types of flow meters were installed: (1) A line meter between the irrigation-pipe joints and (2) a saddle meter in the welldischarge pipe. These meters allowed determination of the total volume of water applied to a crop at each irrigation set. As a check on the accuracy of these meters, instantaneous discharge measurements were made of the flow from these wells.

During 1977, discharges from wells ranged from 140 to $910 \mathrm{gal} / \mathrm{min}$, with a median of $510 \mathrm{gai} / \mathrm{min}$. During 1978, discharges from wells ranged from 65 to $1,080 \mathrm{gal} / \mathrm{min}$, with a median of $415 \mathrm{gal} / \mathrm{min}$.

During 1977, a wet year, about 6,800 acre-ft of ground water was pumped; During 1978, a dry year, about 7,900 acre-ft of water was pumped. The average pumpage for 1977-78 was 7,400 acre-ft/yr. 
The Ogallala aquifer generally is considered to be unconfined, al though temporary semiconfined conditions may exist locally owing to the heterogeneous nature of the deposits. Storage coefficients of 0.08 to 0.18 in Wichita County were reported by Slagle and Weakly $(1976, \mathrm{p} .11)$. They also reported transmissivities from aquifer tests of 5,700 to $12,000 \mathrm{ft}^{2} / \mathrm{d}$ and specific capacities of 12 to 32 (gal/min)/ft of drawdown.

Well drillers commonly do extensive test drilling before deciding on a site to drill an irrigation well. This allows the driller to place the irrigation well in a location where highest transmissivities occur. Therefore, the reported transmissivities from aquifer tests probably are 1 arger than the average transmissivity values in the area.

Transmissivities also were estimated on the basis of lithology at two test holes (Kume and others, 1979, p. 16-17 and 21-22). At test hole 17-35W-29CBC, a transmisssivity of $5,100 \mathrm{ft}^{2} / \mathrm{d}$ and a hydraulic conductivity of $74 \mathrm{ft} / \mathrm{d}$ were determined. At test hole $17-36 \mathrm{~W}-26 \mathrm{CBB}$, a transmissivity of $2,700 \mathrm{ft}^{2} / \mathrm{d}$ and a hydraulic conductivity of $37 \mathrm{ft} / \mathrm{d}$ were determined. Aquifer tests made at these sites were inconclusive owing to interference from irrigation pumping in nearby areas.

The water stored in the aquifer within the intensive-study area during 1977 was estimated to be 61,000 acre-ft. This estimate was based on a summation of the product of each area, as shown in figure 8 , that was computed by the average saturated thickness during 1977 multiplied by an assumed specific yield yield of 0.17 .

Not all of the ground water in storage is recoverable by large-capacity irrigation wells because drawdown in the well is necessary to induce 1 ateral inflow from the aquifer. When saturated thicknesses decrease to about 50 feet or less, well yields will be reduced to much less than the initial yields. Thus, it will be even more difficult and inefficient to recover the ground water in the remaining 5 to 15 feet of saturated thickness. Assuming that the last 10 feet of saturated thickness is not recoverable for irrigation, the recoverable ground-water storage would be about 50,000 acre-ft. 
The water in the Ogallala aquifer is of suitable quality for most domestic, stock, municipal, and irrigation purposes. Eight irrigation wells were sampled, as shown in figure 2. The chemical analyses are listed in Kume and others (1979, p. 26).

The concentrations of most major dissolved constituents were less than the limits recommended by the Kansas Department of Health and Environment for use in drinking water. However, the concentration of dissolved fluoride, which ranged from 1.7 to $2.2 \mathrm{mg} / \mathrm{L}$ (milligrams per 1 iter), exceeded the recommended limit. The water contained an average of $224 \mathrm{mg} / \mathrm{L}$ of hardness, which is considered very hard.

The water in the 0gallala is classed, on the basis of the predominant ions, as a calcium bicarbonate type. Concentrations of calcium ranged from 45 to $59 \mathrm{mg} / \mathrm{L}$, and bicarbonate ranged from 193 to $278 \mathrm{mg} / \mathrm{L}$. Specific conductance ranged from 520 to 610 micromhos per centimeter at $25 \mathrm{C}$ and averaged 560 micromhos.

Based on a classification of water showing suitability for irrigation (U.S. Salinity Laboratory Staff, 1954), the water has a low- to medium-sodium hazard and a medium-salinity hazard. Water with a low-sodium hazard can be used for irrigation with little danger of developing harmful concentrations of exchangeable sodium. Medium-sodium water will present an appreciable sodium hazard in finetextured soil having a high cation-exchange capacity, unless gypsum is present in the soil. This water can be used on coarse-textured or organic soils that are relatively permeable. Water with a medium-salinity hazard can be used for irrigation if a moderate amount of leaching occurs.

\section{IRRIGATION EFFICIENCY}

Water management has become a major factor in the farm program in western Kansas because of a declining water table combined with decreasing irrigationwell production. An effective water-management program is important to irrigators because it may help to make water users more water conscious and water efficient.

Benefits of an effective water-management program include cost savings in energy and labor through efficient water use and pumping plants, thus decreasing the demand on the aquifer and prolonging its use as a water resource. Other useful benefits include an increased knowledge of the water budget, groundwater inflow and outflow, available ground-water reserves, water consumption, and improved irrigation techniques and irrigation efficiency. Improved techniques include effective use of precipitation and available soil moisture and efficient irrigation scheduling. 
Soil-moisture status is one of the most important aspects of irrigation management for crop production because it dictates how long a crop can continue to grow without additional water either from irrigation or rainfall. Gypsum blocks, tensiometers, and gravimetric moisture content were used to determine soil moisture in the study area.

Gypsum blocks were used to measure the amount of soil moisture available to plants. For irrigation purposes, the water of importance is the amount of available soil moisture that can be extracted from a soil by the roots of plants. Gypsum blocks operate best in soils that consist mostly of clay or silt and very little sand (Kume and others, 1979, p. 38).

Soil moisture ranges from field capacity (maximum amount held by soil after gravity drainage) to permanent wilting point (virtually all available moisture has been used by plants) or from 0 to 15 bars of moisture tension Ideally, gypsum blocks are used to determine the available soil moisture in a field so that irrigation water can be applied before 50 percent of the available moisture is depleted in the first 3 feet of the soil profile. In addition to determining available soil moisture for irrigation scheduling, gypsumblocks at various depths can be used to determine moisture penetration, the amount of moisture replenishment at different depths, deep percolation losses, moistureproblem areas within a field, and the effectiveness of rainfall.

Tests were conducted using gypsum blocks that were buried at depths of $12,24,36,48$, and 60 inches at each station. The gypsum blocks were located in the first and last irrigation set, or parts of the field to be irrigated, at the upgradient and downgradient sites. These blocks were located far enough from the end of the field to minimize the initial wetting and tailwater effects in the rows. Usually, a minimum of four stations were established in each field. An example of monitoring the available soil moisture is shown (fig. 11) for test field 17-36W-27DBC. Gypsumblocks were installed at three sites through

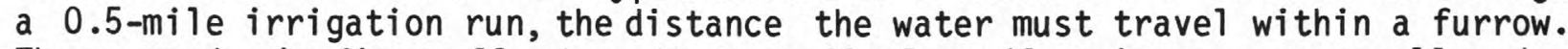
Three graphs in figure 11 show that available soil moisture was usually adequate in the top of the field (W5) and in the end of the field where tailwater backed up or stood (E5). Available soil moisture was generally inadequate in the middle of the field (M5) because of the long (0.5-mile) irrigation runs.

Tensiometers are ceramic-tipped tubes filled with water and inserted vertically in the soil to measure soil-moisture tension. They were installed at depths of 12, 24, and 36 inches adjacent to the gypsum blocks in several test fields. Tensiometers were not successful in the silt-loam soils of the study area because the calibrated range of zero to 1-bar tension represents only 20 to 30 percent of the available moisture. As the soil dries and shrinks away from the porous tip, tension is permanently broken. 


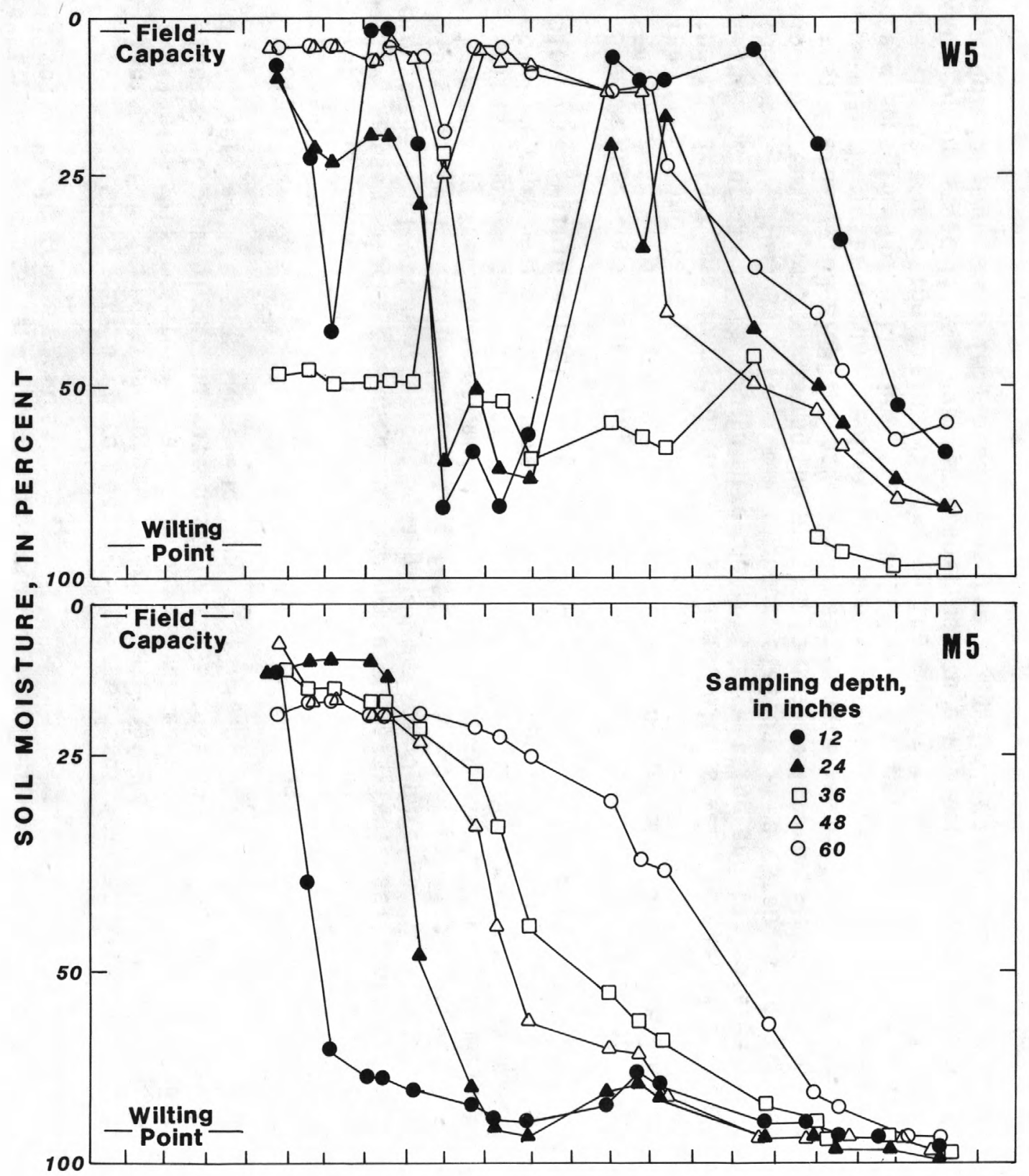



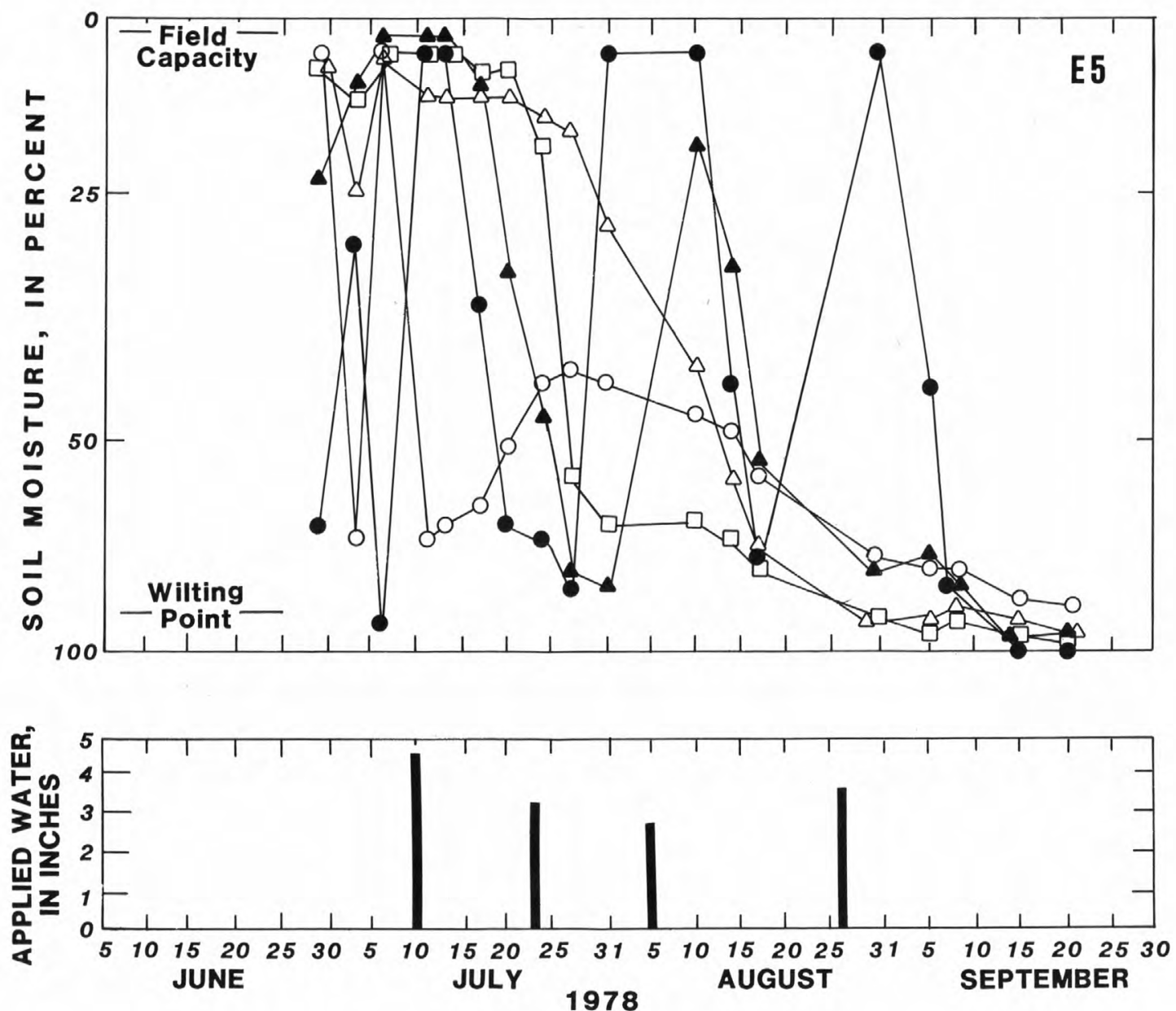

Figure 11.--Soil moisture and irrigation water applied in test field 17-36W-27DBC. 
Soil-moisture content was determined also by gravimetric weighing of soil samples selected from several test fields during 1978 (Kume and others, 1979, p. 39-42). Soil samples were collected at 1-foot intervals to depths of 5 feet. Sampling was repeated as many as four times in the same fields during the growing season. The available soil moisture (percent by weight) was determined by weighing the sample before and after drying in an oven.

\section{Irrigation Scheduling}

A valuable water-management tool, if applied correctly, is irrigation scheduling. Irrigation scheduling implies that only needed water is used. Water is applied on a crop only in amounts necessary to insure an adequate quantity of available soil moisture.

Irrigation scheduling was difficult during the study because rainfall during the growing season was abnormally large during 1977 and abnormally small during 1978 (Kume and others, 1979, p. 36-37). In addition, it was difficult for some irrigators to adequately water fields because of the decreased irrigation-well yields. Only one field of those monitored during 1977 had more water applied than necessary to maintain a good moisture relationship in the soil profile. Irrigation scheduling may have resulted in a water savings of 2 in/acre.

Water-use efficiency is a good measurement for judging the effectiveness of irrigation scheduling. In southwestern Kansas, corn has a water-use efficiency of 5.4 to 6.2 bu/in of water for one preplant irrigation and two inseason irrigations. For cornhaving one preplant irrigation and three in-season irrigations, the water-use efficiency is 4.6 to 5.2 bu/in. These water-use efficiency data were derived from field tests at the Garden City Branch and Tribune Experiment Stations of Kansas State University in western Kansas. Wateruse efficiencies in four test fields during 1977 ranged from 3.7 to $6.7 \mathrm{bu} / \mathrm{in}$ and averaged 5.7 bu/in of water. The low efficiency of 3.7 bu/in may have been caused by insufficient water during a critical stage of plant growth. Records of average crop yields in test fields and of crop acreage in the intensive-study area are listed by Kume and others (1979, p. 48-49).

For proper irrigation scheduling, the minimum amount of water per acre available to the crop should be 5 to 7 gal/min for full irrigation of corn and 5 to $6 \mathrm{gal} / \mathrm{min}$ for sorghum. The amount of water per acre in the monitored fields during 1977 ranged from 2.8 to $7.5 \mathrm{gal} / \mathrm{min}$. This indicates that severe crop-stress problems would have resulted if rainfall had not been abundant. Irrigators having wells that were unable to supply 5 to $7(\mathrm{gal} / \mathrm{min}) / \mathrm{acre}$ would have had shortages without the additional rainfall. 
Crop-water requirements differ at various stages of growth. Corn yields are sensitive to water availability during the periods when the corn tassels, sheds pollen, silks, and fills its grains (Sanghi and Klepper, 1977, p. 282). Irrigation scheduling during this critical period of plant growth will have an important impact on maintaining crop yields. Another conservation method is the filling of the soil profile to a depth of 60 inches with moisture by preirrigation prior to planting. Also, an irrigator could stagger the planting dates and use different maturity hybrids so that the whole field will not be at a critical stage of growth at the same time. This would allow staggered irrigations if the supply of water was limited.

\section{Efficient Pumping Plants and Wells}

Recent energy shortages and increasing energy costs have focused attention on conservation of the amount and rate of energy consumption by pumping plants. Efficient pumping plants and wells generally use less energy and cost less to operate.

The power factor, which is the amount of energy needed by the pumping plant to pump 1 acre-ft of water, can give a general indication of the efficiency of a pumping plant and well. A large power factor indicates a small discharge of water with a large energy consumption, and a small power factor is evidence of a large discharge of water with a small energy consumption. Power factors for irrigation wells in the study area are listed by Kume and others (1979, p. 44-45). These measurements have assisted some irrigators in determining well yield, energy usage, and cost per acre-foot of water pumped.

During this study, the power factors of the irrigation wells were determined by measuring the instantaneous discharge of the well and using meter readings to calculate the rate of power consumption in cubic feet of natural gas, kilowatt hours (kWh) of electricity, or gallons of diesel fuel. During 1977, the power factors for natural gas ranged from about 4,300 to $31,000 \mathrm{ft}^{3} / \mathrm{acre}-\mathrm{ft}$ of water and averaged $9,800 \mathrm{ft}^{3} / \mathrm{acre}-\mathrm{ft}$; for electricity, power factors ranged from about 270 to $650 \mathrm{kWh} / \mathrm{acre}-\mathrm{ft}$ and averaged $510 \mathrm{kWh} / \mathrm{acre}-\mathrm{ft}$; and for diesel fuel, averaged $30 \mathrm{gal} / \mathrm{acre}-\mathrm{ft}$. Inefficient wells with 1 arge power factors generally indicate the need for some maintenance and an adjustment of the pumping plant and well.

Proper construction, which also increases well efficiency, includes selection of proper dimensional factors for the well structure and selection of materials to be used in construction. A properly constructed well admits a maximum amount of water from an aquifer without excessive loss of hydraulic head in the well. Installation of a well screen or perforated casing of proper slot openings and a gravel pack opposite the entire aquifer generally are required. Development of the we11--pumping to remove drilling mud and fine-grained material from the aquifer adjacent to the well--also is required. 


\section{WATER-SUPPLY MANAGEMENT \\ USING A DIGITAL COMPUTER MODEL}

Ground-water management is becoming increasingly important in west-central Kansas because of dwindling ground-water resources. Management decisions need to be made to prolong the life of the Ogallala aquifer. Digital computer flow These models incorporate the flow equations, the aquifer characteristics, and the pumping stresses in order to predict the water-level response. Such a model was used to simulate the ground-water flow of the Ogallala aquifer for existing conditions and to predict the response of the aquifer to various management schemes for the intensive-study area.

A digital computer model is only a mathematical representation of an aquifer of an aquifer system and is not as complex as a real aquifer system. Simplifications of the aquifer characteristics are necessary in order to represent the aquifer system. Several management plans for the intensive-study area were tested with a digital computer model.

Mathematical Model

The two-dimensional finite-difference ground-water flow model described by Trescott, Pinder, and Larson (1976) was used to simulate the ground-water flow in the Marienthal area. The strongly implicit procedure was used to solve the ground-water flow equations for the hydraulic head values.

The partial differential equation of ground-water flow in a water-table aquifer in two dimensions may be written as:

$$
\frac{\partial}{\partial x}\left(K x x b \frac{\partial h}{\partial x}\right)+\left[\frac{\partial}{\partial y}\left(K y y b \frac{\partial h}{\partial y}\right]=S y \frac{\partial h}{\partial t}+W(x, y, t),\right.
$$

where

$$
\begin{aligned}
\text { Kxx, Kyy }= & \text { the principal components of the hydraulic conductivity } \\
& \text { tensor ( } \left.\mathrm{Lt}^{-\top}\right) ; \\
\mathrm{b} & \text { saturated thickness }(\mathrm{L}) ; \\
\text { Sy } & \text { specific yield (dimensionless); and } \\
\mathrm{h} & =\text { hydraulic head }(L) .
\end{aligned}
$$

This finite-difference model was set up to simulate ground-water flow in the Ogallala Formation as a single-layer system that can be described in two dimensions. 
The size of the model area, about 480 square miles, is necessarily much 1 arger than the intensive-study area, which is located in the center of the of the model area (fig. 12). The boundaries of the model area were situated a great enough distance from the intensive-study area so that simulated well-field pumping in the intensive-study area will cause negligible changes in hydraulic head at the boundary of the model area. A more detailed description of model boundaries is given in the section "Boundary Conditions."

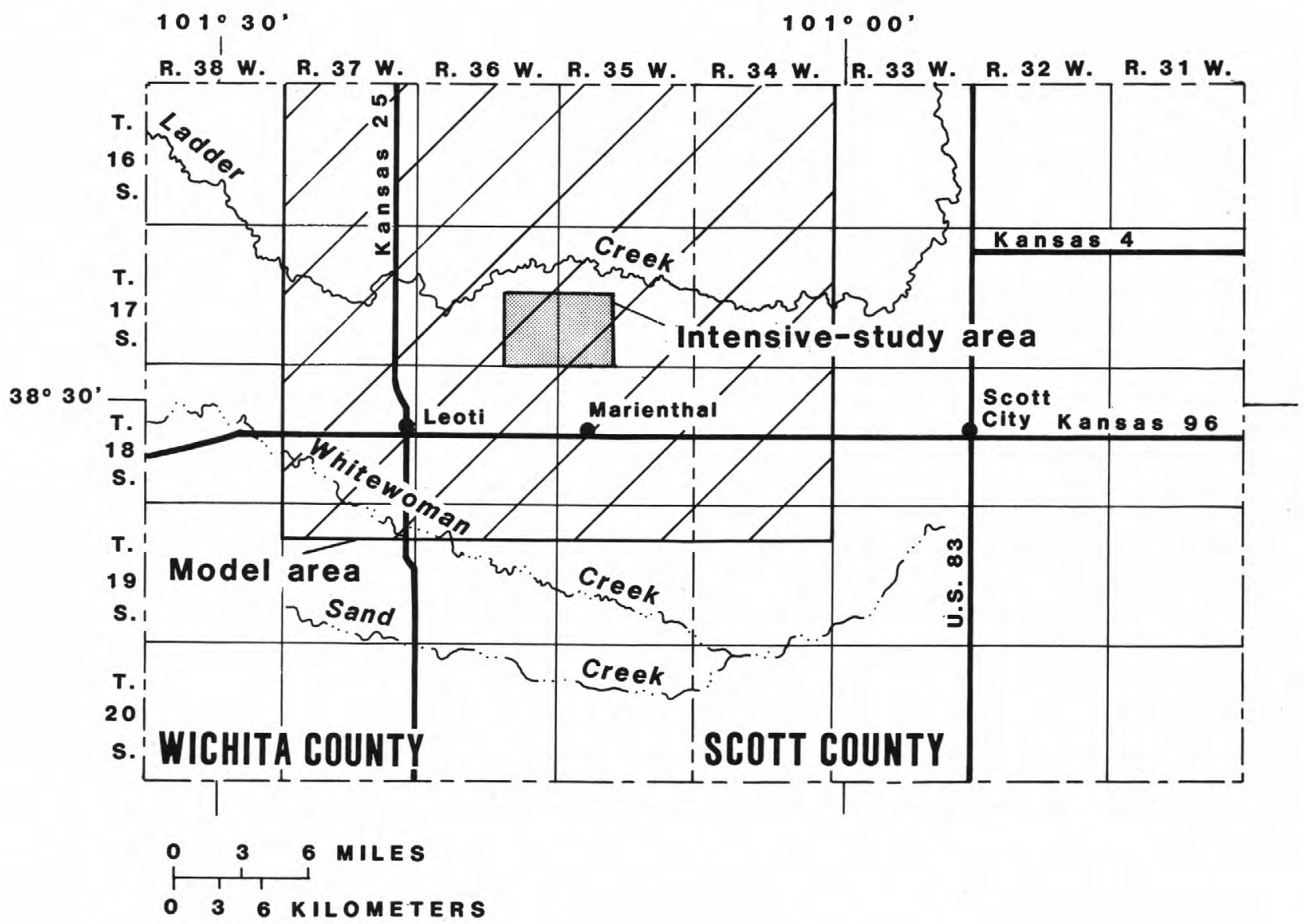

Figure 12.--Location of intensive-study area and model area in Wichita and Scott Counties, Kans. 
As required by the model, the area was divided into a grid of rectangular blocks, as shown in figure 13. In each block, the aquifer properties are assumed to be uniform.

A variable-size grid was used for the model area. Block dimensions were 0.5-mile square in the intensive-study area to provide for the necessary detail. Block dimensions are increased away from the intensive-study area to provide the desired detail with a minimum number of nodes.

Best estimates of hydraulic conductivity, natural recharge, boundary conditions, specific yield, bottom of the aquifer, pumpage, and 1950 equilibrium water levels were specified as input data to each block of the model. The model was then run to compute the ground-water levels and the ground-water flows.

An important source of error in using the model can be the accuracy of the aquifer characteristics, such as hydraulic conductivity, natural recharge, and specific yield. Data from aquifer tests for single wells must be qualified because they are representative for only small areas and can be extrapolated to large areas in the model only with caution. Information from aquifer tests and lithologic logs were used for initial estimates and to bracket high and low values of hydraulic conductivity and specific yield.

The model was calibrated for both steady-state and transient-state conditions. The steady-state model was calibrated first to calculate an initial water-level surface that would mathematically satisfy the input parameters and be representative of equilibrium, or predevelopment, conditions. Then the transient model was calibrated to incorporate the changing stresses, such as pumpage, boundary inflow and outflow, time, and ground-water storage. The equilibrium water-level surface calculated in the steady-state model was used as the initial water-level surface in the transient-state model.

Water-level changes resulting from stresses were calculated by the transientstate model for the calibration period (1951-77). Estimates of actual hydrologic parameters were used in the model. These estimated parameters were adjusted, within justifiable limits, until the water-level changes calculated by the model reasonably matched the historic water-level changes that had been measured in the model area. Calibration to match the measured water-level conditions (1951-77) insures that the transient-state model would reasonably predict future water-1evel changes that would occur during the next 10 years. 


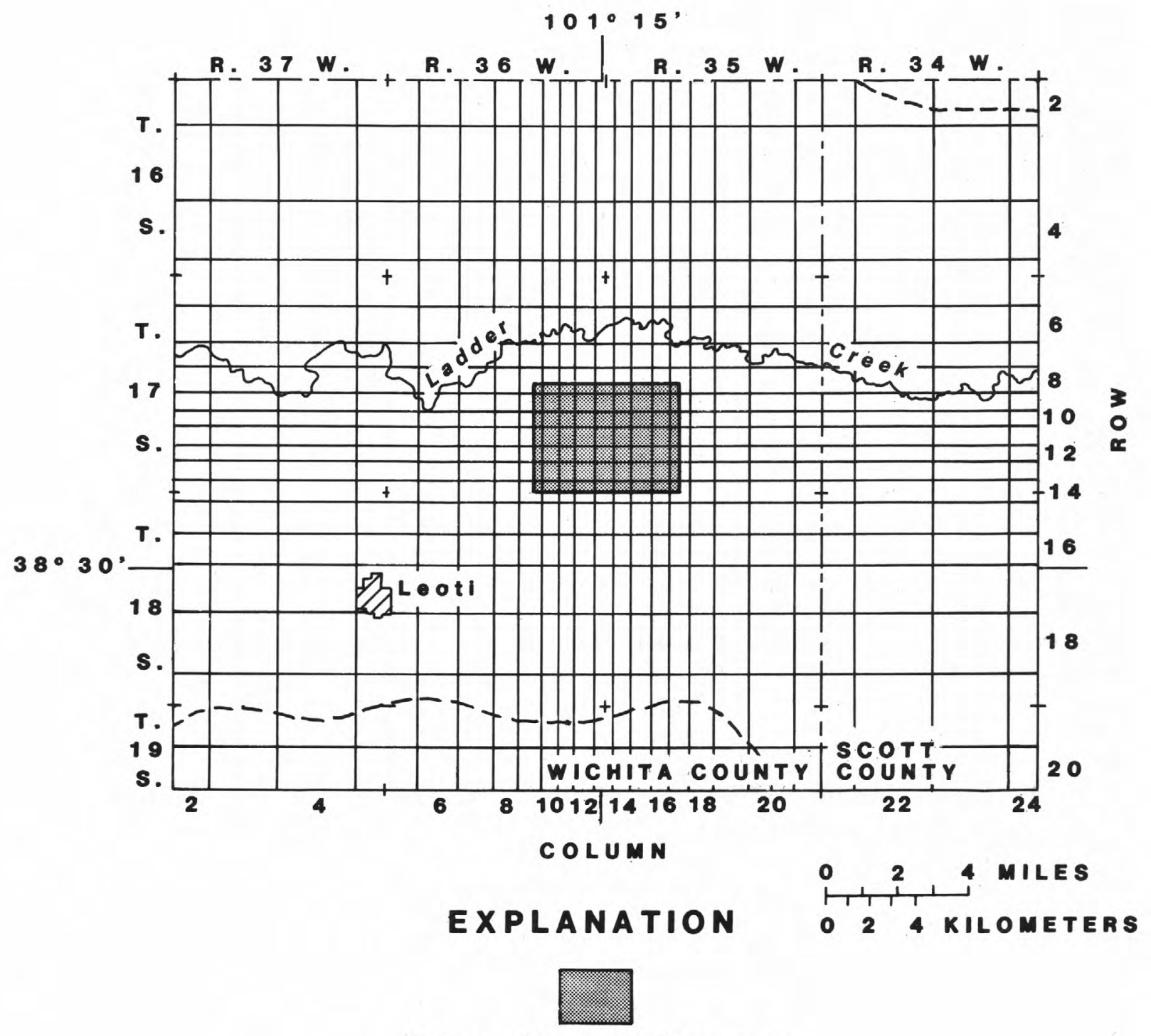

Intensive-study area

Aquifer boundary

Figure 13.--Finite-difference grid used in mathematical model. 
Prior to extensive irrigation in west-central Kansas, the ground-water levels were in an equilibrium or steady-state condition. Natural recharge equaled natural discharge, and water levels varied little over long periods of time. The steady-state model of the area is generally representative of conditions prior to the mid-1950's.

Hydrologic parameters used in the steady-state model are the initial estimates of head (water levels), hydraulic conductivity, bottom of the aquifer, leakage from Ladder Creek, and natural recharge. With these initial estimates, the steady-state model computes hydraulic heads that mathematically satisfy these parameters and represent steady-state conditions.

During 1950, discharge from wells was relatively small and had a negligible effect on equilibrium conditions that existed during that time (Bradley and Johnson, 1957, p. 48). The steady-state model was calibrated to match the hydraulic heads that were measured during 1950-51 by Bradley and Johnson (1957, p. 105-109).

A uniform value of recharge was used in the model. This recharge was the amount of water from precipitation that entered the aquifer from nonirrigated farmland, tailwater pits, road ditches, and ephemeral streams. Recharge in Wichita County is about 1 percent of the precipitation (18-19 inches) on nonirrigated land (Slagle and Weakly, 1976, p. 8). After calibration of the steadystate mode1, recharge of $0.28 \mathrm{in} / \mathrm{yr}$ best fit the measured water-level conditions.

The bedrock (Niobrara Chalk) underlying the Ogallala Formation forms a relatively impermeable lower limit of the aquifer. Altitude of the Niobrara surface was specified in the model based on data from Slagle and Weakly (1976) and from test drilling and available drillers' well logs. The altitude was not adjusted for calibration purposes.

The hydraulic heads during 1950 on the east and west boundaries are better known than ground-water flow into and out of the model area. Therefore, the east and west boundaries of the model area during steady-state conditions were considered as constant heads, where water levels do not change. The north and south boundaries of the model area were considered as "no-flow" boundaries because the saturated thickness of the Ogallala Formation pinches out. 
Hydraulic conductivity in the model area was initially estimated at 75 $\mathrm{ft} / \mathrm{d}$, based on lithologic logs of test holes drilled in the intensive-study area and aquifer tests from previous studies. During calibration, the hydraulic conductivity was reduced from 20 to 60 percent in three areas outside the intensive-study area (fig. 14). These reductions in hydraulic conductivities were within the range of values based on lithology from drillers' logs in these areas. Inspection of the water-table contour map in figure 15 indicated that the areas north of Ladder Creek and in the southeast section of the model area had relatively steeper gradients than the area south of Ladder Creek in the vicinity of the intensive-study area. This could be correlated with smallest transmissivities in the areas where the steepest gradients are found. With the reductions in hydraulic conductivity, as shown in figure 14, the 1950 watertable contours reasonably matched the water-table contours simulated by the steady-state model (fig. 15).

Transient-State Model

With the increasing development of irrigation beginning in the 1950's, equilibrium conditions in the model area ceased to exist. The number of irrigation wells in the model area has increased steadily to 758 in 1978 (fig. 16). The net withdrawal of ground water from the aquifer began to exceed the natural recharge. This condition of withdrawing the ground water from the aquifer faster than it can be replenished by natural recharge has continued and even accelerated. The result has been dramatic water-level declines. Hydrographs of wells in the model area indicate that water levels have been declining as much as 4 to $6 \mathrm{ft} / \mathrm{yr}$ (fig. 6).

The transient-state model was used to calculate water-level changes that have occurred in the aquifer since 1951. This was done by generation of a hydraulic-head surface that mathematically satisfies the input parameters. Parameters included in the transient-state model were natural recharge, hydraulic conductivities of the aquifer and streambed, streambed thickness, bottom of the aquifer, initial-head surface, specific yield, pumpage, and ground-water inflow and outflow at the model boundaries.

\section{Pumpage}

Some parameters, such as pumpage, generally change from year to year, and the actual amount of ground water pumped in the model area since 1951 is very difficult to quantify. Irrigators in the area are required to report their annual ground-water usage to the Kansas State Board of Agriculture, Division of Water Resources. A search of the unpublished records indicated that some data may be inaccurate or incomplete for use in determining reliable pumpage amounts. 


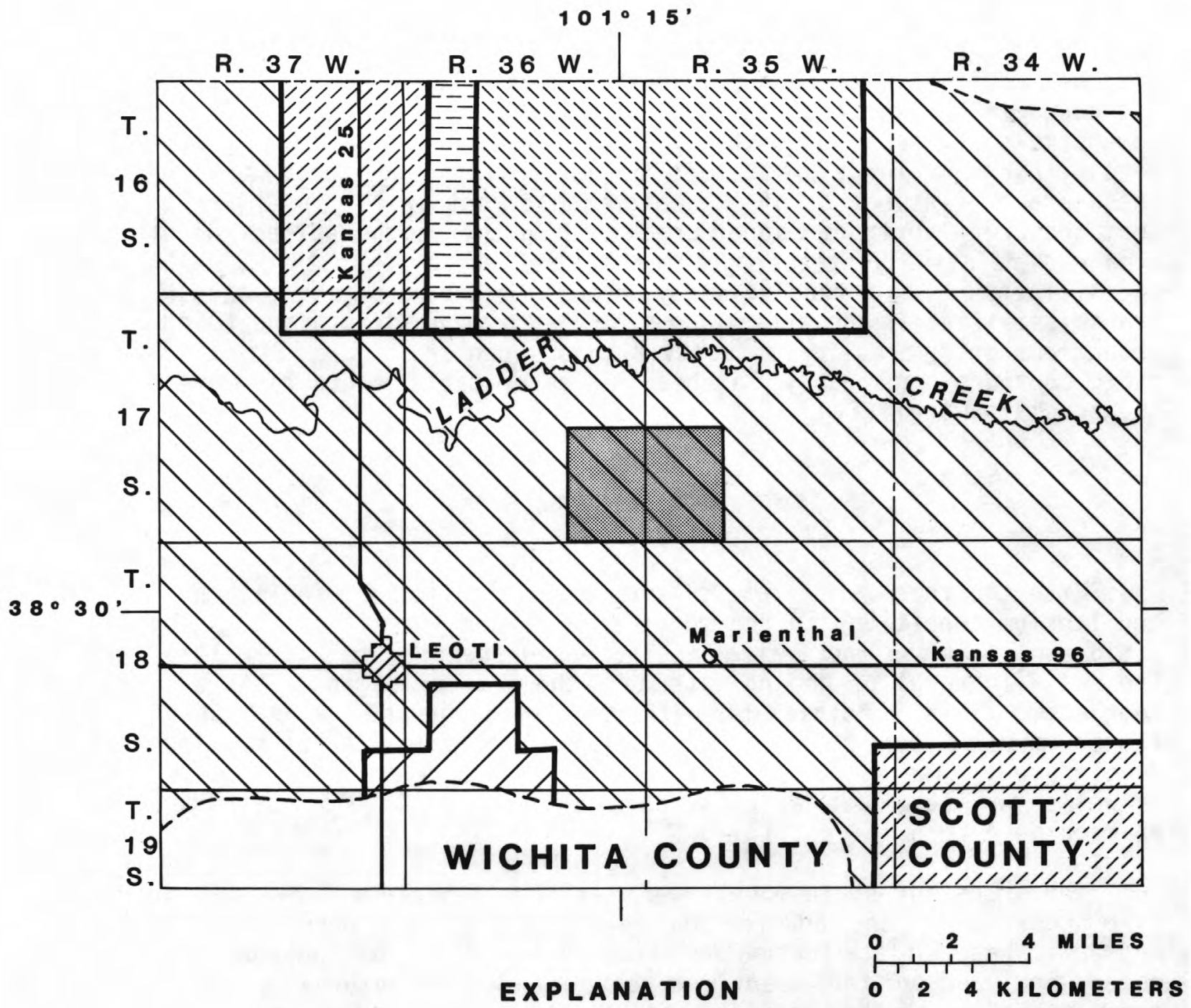

Hydraulic conductivity,

in feet per day
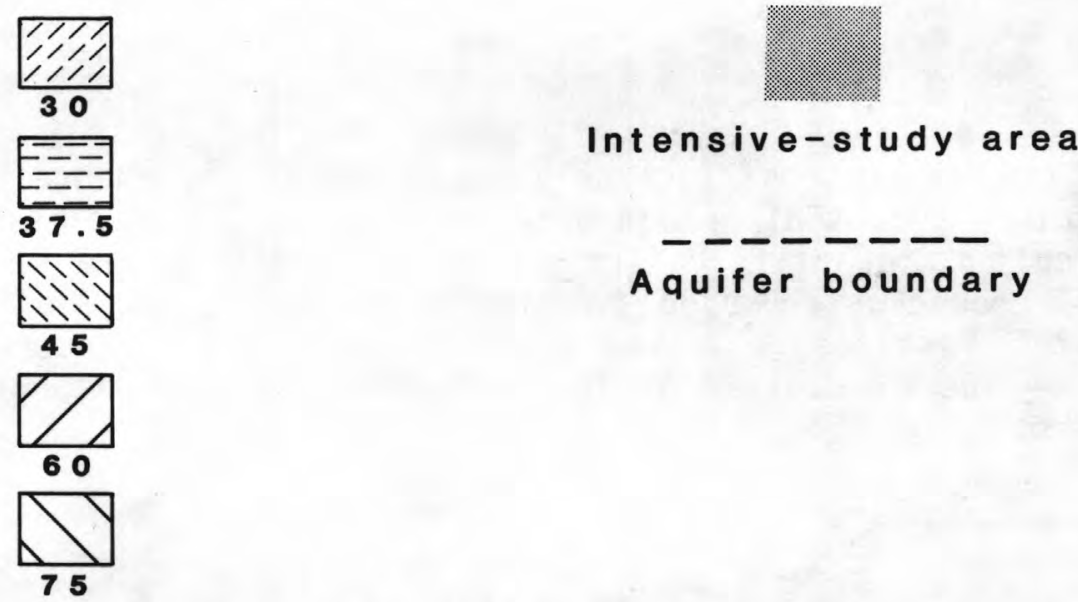

Aquifer boundary

Figure 14.--Hydraulic conductivity used in steady-state model. 


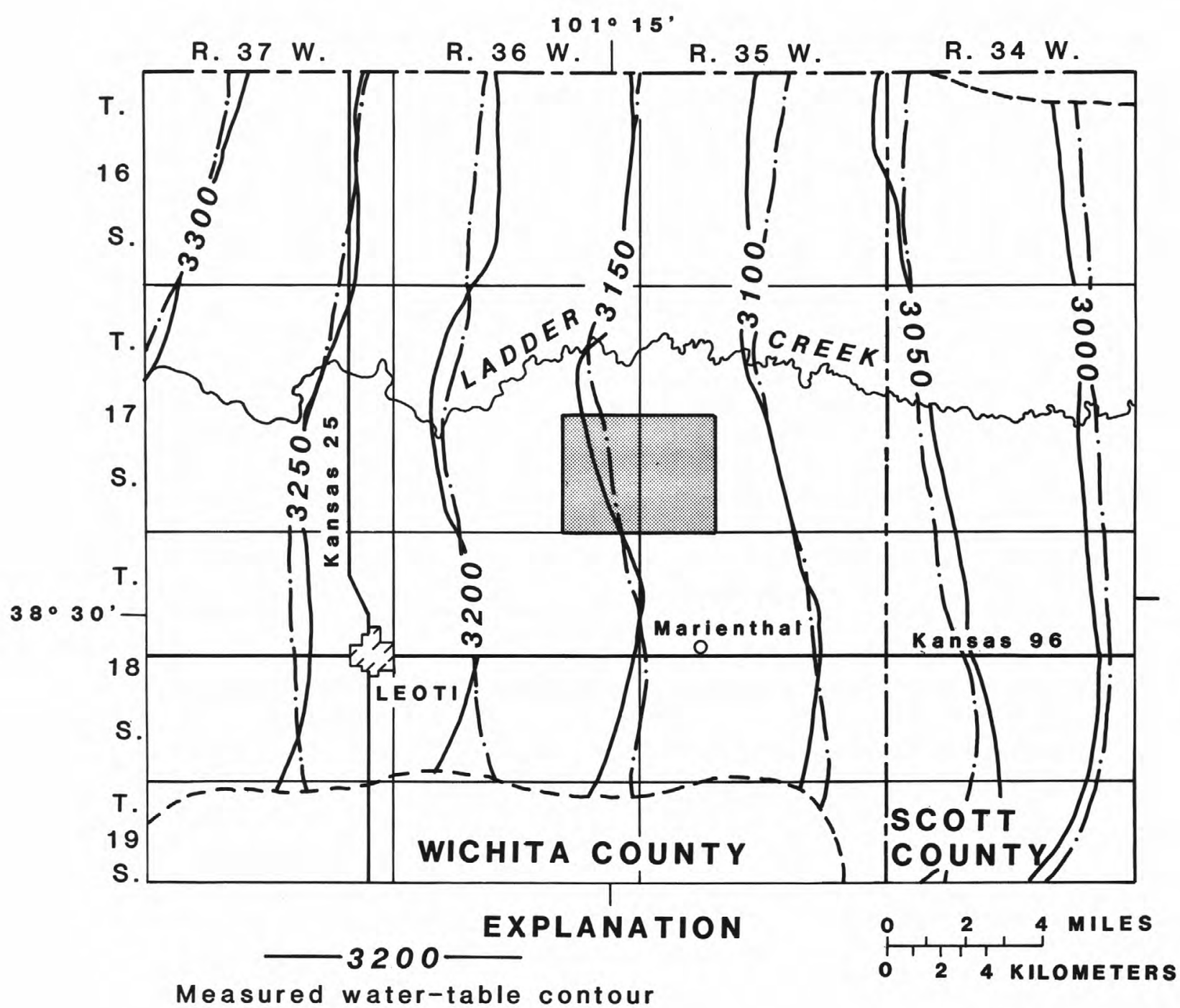

Shows the observed altitude of water table, 1950-51. Contour interval 50 feet. Datum is NGVD of 1929

$$
-\cdot-3200-\cdot-
$$

Simulated water-table contour

Shows the simulated altitude of water table, 1950-51. Contour interval 50

feet. Datum is NGVD of 1929

Figure 15.--Comparison of 1950-51 water-table contours from measurements and from steady-state model. 


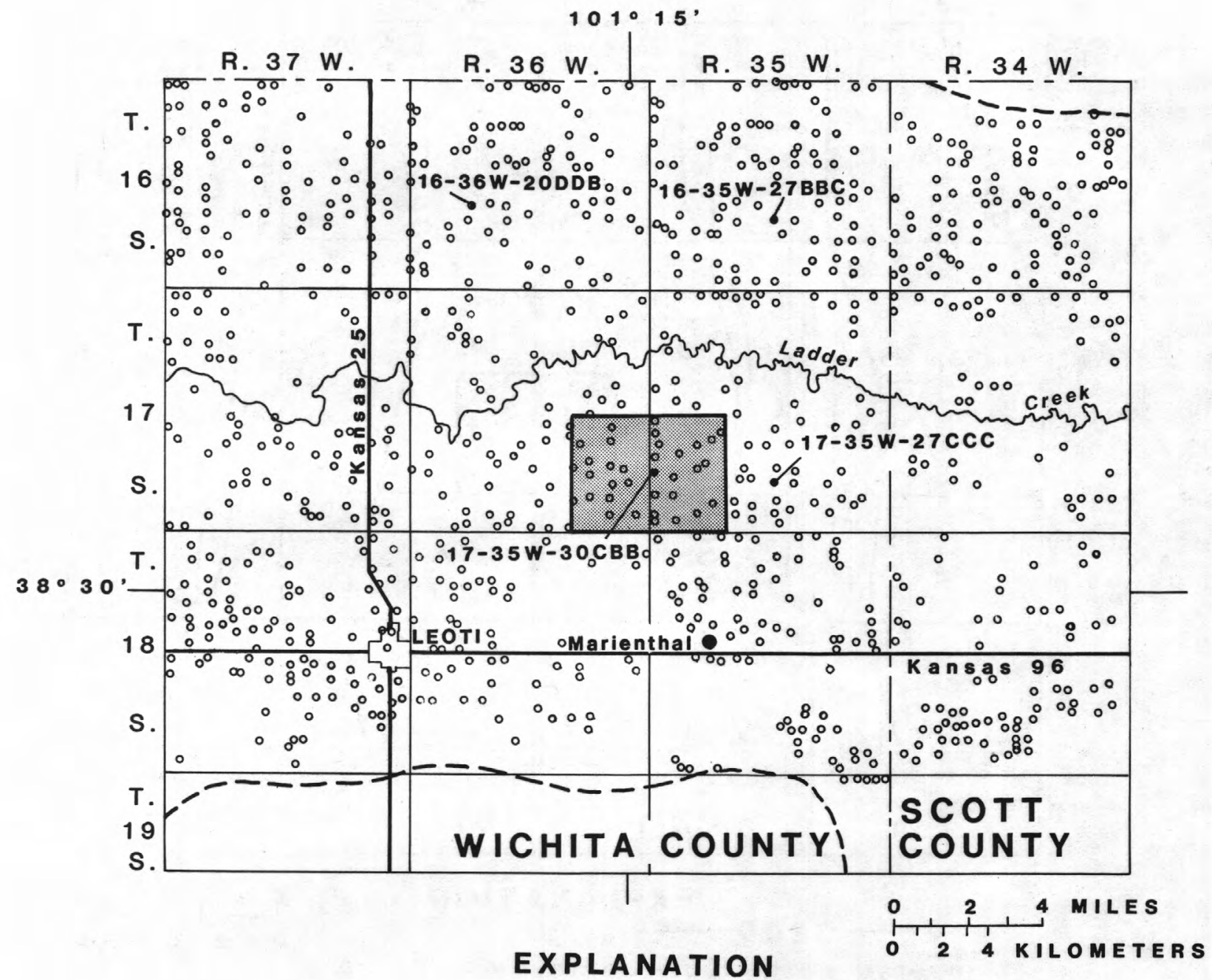

EXPLANATION

Irrigation well

Observation well

Hydrographs for these wells are shown in figure 22

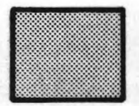

Intensive-study area

Aquifer boundary

Figure 16.--Locations of irrigation wells in 1978. 
Crop-water demand and the amount of irrigated acreage were used to estimate annual pumpage in the model area. A soil-zone model used by Lappala (1978, p. 94) in Nebraska estimates the amount of water, in addition to precipitation, needed to grow an irrigated crop. The model tabulates soil moisture and cropwater demand for various crops and totals the irrigation needed to maintain the available soil moisture at 50 percent. Input parameters to the soil-zone model include precipitation, temperature, potential evapotranspiration, and soil characteristics. Crop-irrigation demand was calculated for corn, wheat, grain sorghum, and alfalfa. Yearly estimates of total irrigated acreage for these crops were obtained from the annual reports of the Kansas State Board of Agriculture (1951-77). The annual pumpage from 1951 through 1977 was calculated based on annual changes in crop acreage and crop-irrigation demand (fig. 17).

Precipitation during some months exceeds crop-water demand. Crop-water demand was calculated monthly and summed for each year as annual pumpage. The soil-zone model calculates the amount of water that goes to surface-water runoff and to ground-water recharge on irrigated land. When this recharge occurs, it is considered to reach the aquifer instantaneously. This annual volume of recharge from irrigated land was subtracted from the annual volume of pumpage, which resulted in the net annual pumpage from the aquifer.

The total net pumpage was proportioned to each block by the ratio of the number of wells in the grid block to the total number of wells within the model area, such as:

$$
Q_{\text {grid block }}=Q_{\text {model area }}\left(\frac{\text { number of wells in grid block }}{\text { number of wells in the model area }}\right) \text {, }
$$

where

$$
Q=\text { discharge, in cubic feet per second. }
$$

During calibration of the transient-state model, adjustments were made to annual pumpage. Wells installed during the 1950's commonly have had a decrease in well yield of about one-half of their original discharge. Thus, the potential well yield has gradually decreased in the model area as a result of decreasing well efficiency and decreasing saturated thickness. 


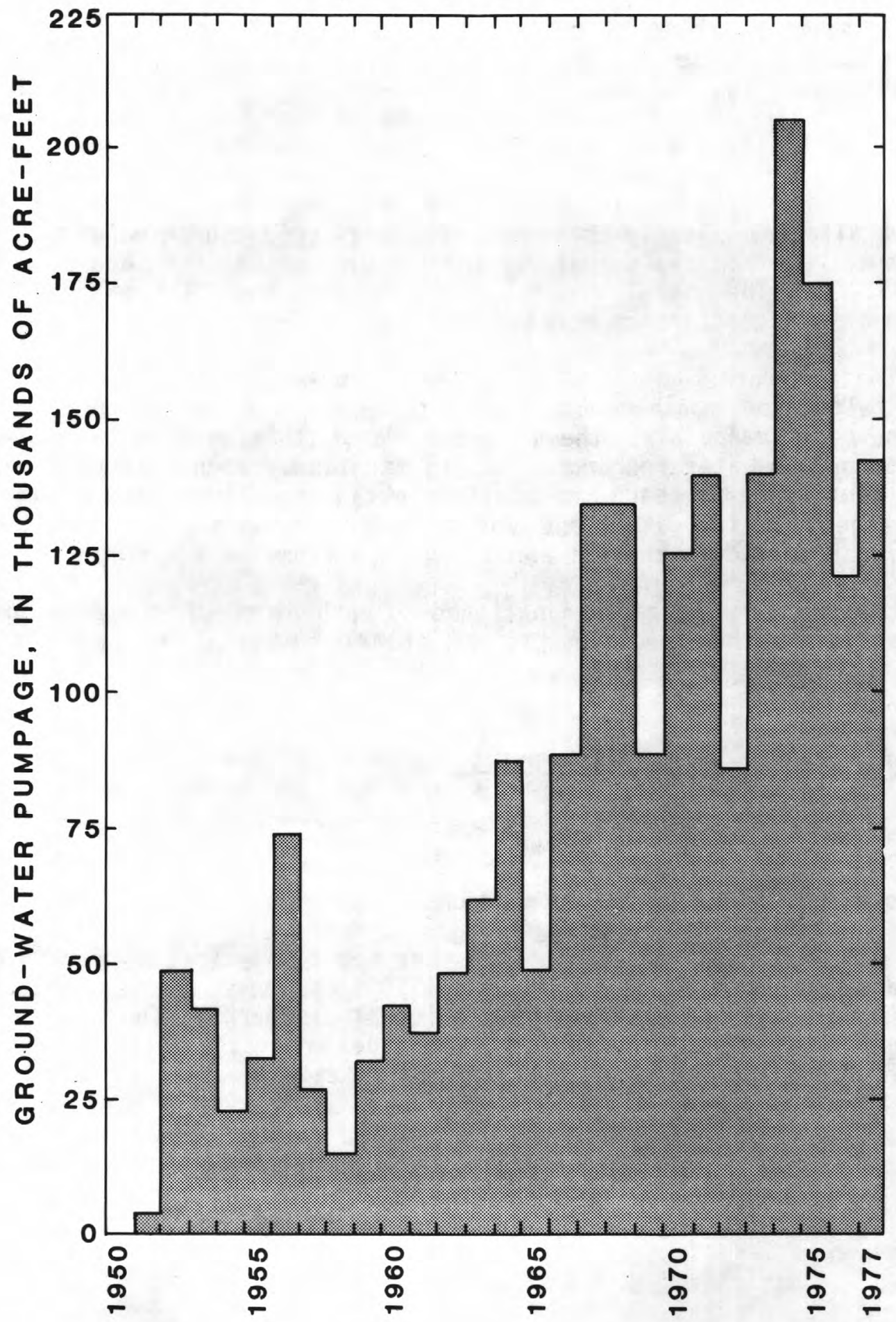

Figure 17.--Ground-water pumpage in model area based on crop consumptive use and irrigated acreage. 
To simulate well-discharge decline in the mathematical model, well discharge at individual nodes was decreased by the function:

$$
Q_{\text {new }}=Q_{\text {input }}\left(\frac{m \text { present }}{m \text { originat }}\right)^{2} \text {, }
$$

where

$$
\begin{aligned}
& Q_{\text {new }}=\text { well discharge after adjustment, in cubic feet per second; } \\
& Q_{\text {input }}=\text { well discharge calculated from soil-zone model in cubic feet per } \\
& \text { second; and } \\
& \quad=\text { saturated thickness at different times, in feet. }
\end{aligned}
$$

This equation was approximated from the Dupuit assumptions in unconfined flow (D. G. Jorgensen, U.S. Geological Survey, written commun., 1978).

Well discharge was adjusted by equation 3 only after saturated thickness at a given node was less than 50 feet. After this time, it was assumed that well yield had decreased to a point where the original pumpage could not be maintained by pumping for a longer period of time. The well discharge was then reduced by using 50 feet as the original saturated thickness (m original) in equation 3 .

With a saturated thickness of less than 50 feet, it was assumed that farmers would pump for a longer period of time to alleviate the shortage of water due to loss of well yield. This is a common practice in the model area.

Viability of the method is shown by comparison of results with a study in Kearny County, southwestern Kansas, by Gutentag and others (1972). In that study, a relationship was developed between the decline in potential well-yield and the decrease in saturated thickness of the 0gallala aquifer. The saturated thickness to potential yield from well-discharge tests in Kearny County is compared with the decrease in well yield calculated from equation 3 (fig. 18). The similarity of the lines indicates that equation $3 \mathrm{can}$ be used in west-central Kansas as a validestimation of declines in well yield when saturated thickness is known.

A check was made to test the accuracy of pumpage data in the model. Using crop-water demand and irrigated acreage, the net amount of ground water withdrawn from the intensive-study area during 1977 was calculated to be 7,019 acre-ft. Using totalizing flow meters and hour meters installed in the irrigation systems, the actual amount of ground water wi thdrawn from the area during 1977 was determined to be 6,800 acre-ft. According to the soil-zone model, irrigation-return flow on irrigated fields in the intensive-study area during 1977 was 20 acre-ft. Thus, the pumpage calculated for the intensive-study area by crop-water demand during 1977 was about the same as actual measurements. 
In modeling studies of large aquifers, model boundaries should be extended to the physical boundaries of the aquifer to eliminate induced errors. The aquifer in the Ogallala Formation in west-central Kansas is long and narrow (fig. 19). Thus, the north and south model boundaries were located at the aquifer's physical boundaries. However, extending the model boundaries to the natural boundaries on the east and west was not feasible due to the enormous amount of data collection.

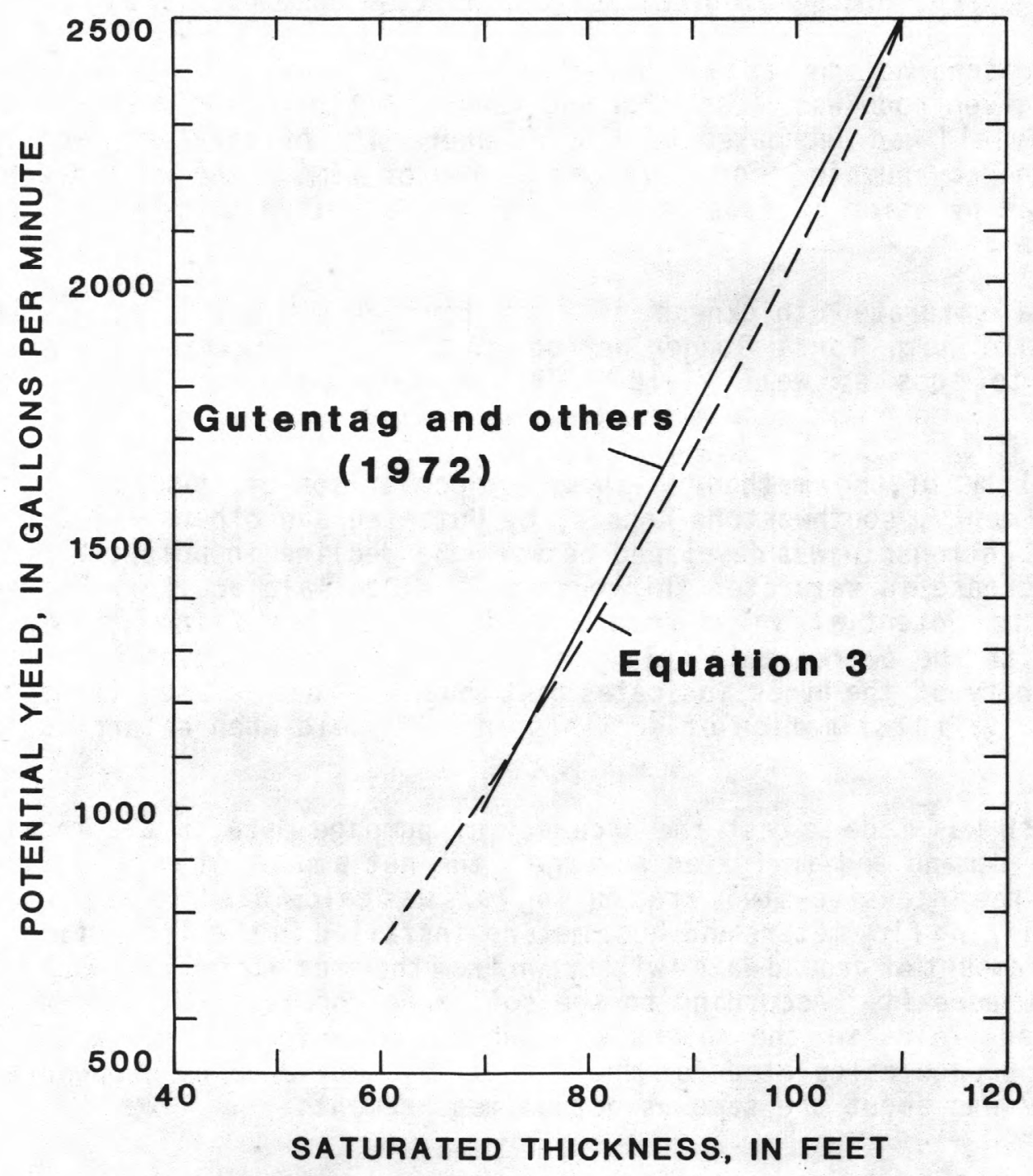

Figure 18.--Comparison of potential well yield and saturated thickness from Gutentag and others (1972) with well-yield decrease (from equation 3). 


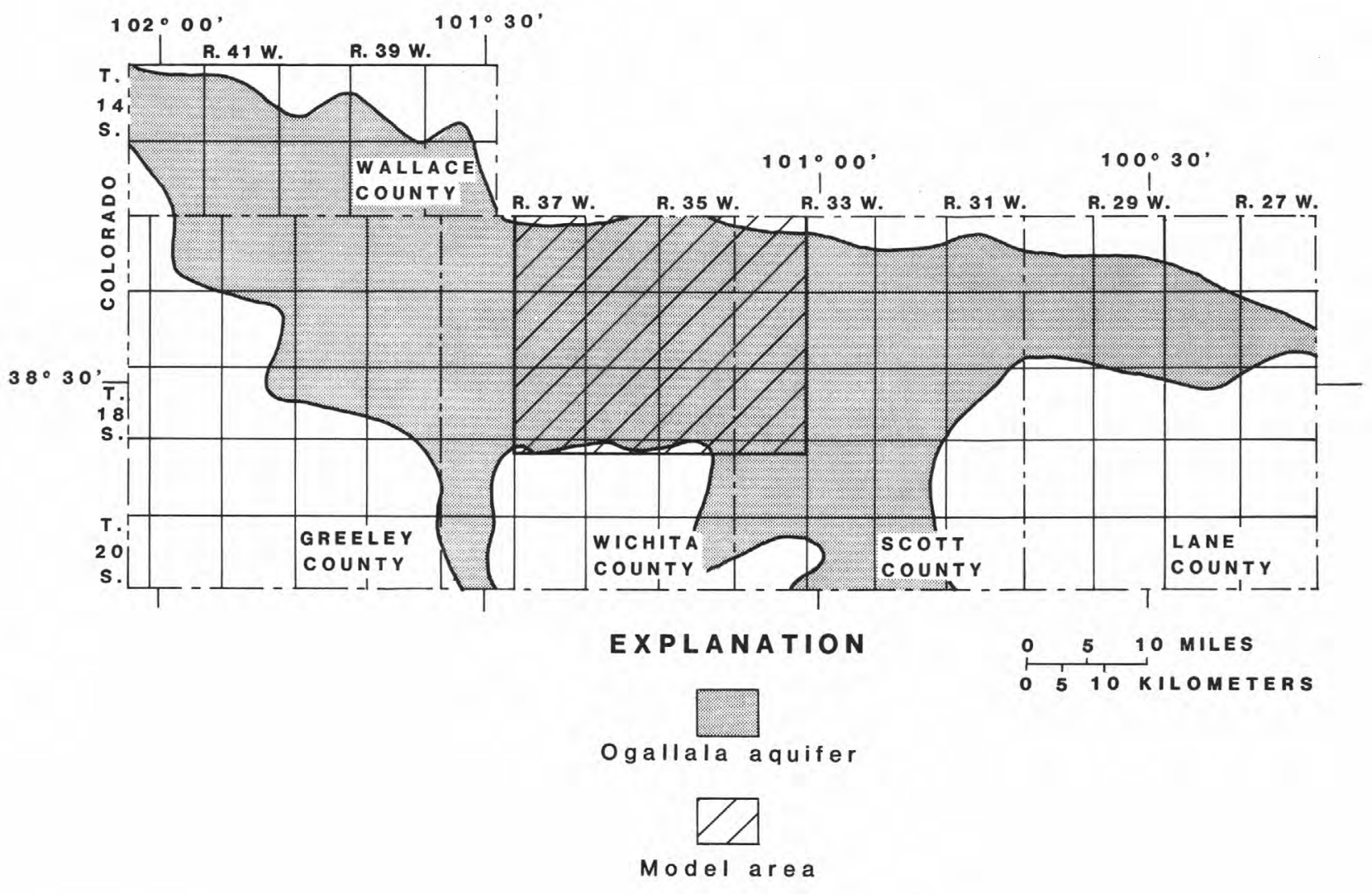

Figure 19.--0gallala aquifer in west-central Kansas and location of model area.

The distance from the intensive-study area to the east and west boundaries was ascertained by determining the radius of influence of a well pumping at a discharge rate typical for the area and located in the center of the intensive-study area. The radius of influence would not reach the boundaries after 10 years of pumping, which is about the length of time used in the model for future predictions. After 38 years of pumping (the total length of time in the model simulation), the drawdown at the boundaries would be 0.05 foot. 
The constant-flux boundary assumes that the gradient across the boundary remains relatively constant through time. If changes in ground-water head were the same on both sides of the boundary, the head gradient across the boundary would accurately reflect actual conditions. Irrigation has developed equally in west-central Kansas, and similar water-level declines have been observed throughout the area.

A constant-flux boundary having zero or no flow was used on the north and south boundaries where the aquifer pinches out. But, the southeast, east, and west boundaries of the model area cannot be accurately treated as either constant head or constant flux during transient-state conditions owing to the continual lowering of heads and decrease in flow. Therefore, a constant-gradient boundary was used that decreases ground-water flow at the node as saturated thickness decreases (fig. 20). The equation used to decrease the ground-water flow across the boundary was:

$\begin{gathered}\text { Qacross the } \\ \text { boundary }\end{gathered}=\left[\begin{array}{l}\text { Qacross the boundary } \\ \text { during equilibrium } \\ \text { conditions }\end{array}\right]\left[\begin{array}{l}\text { saturated thickness at } \\ \text { the simulation time } \\ \hline \text { saturated thickness during } \\ \text { equilibrium conditions }\end{array}\right]$,

where

$Q=$ discharge, in cubic feet per second.

The base flow in Ladder Creek was maintained by natural discharge from the aquifer during the 1950's. The declining ground-water levels resulted in a gradual decrease in discharge to the stream. When the head in aquifer aquifer declined below the streambed in the late 1950's, base flow ceased. In the mathematical model, Ladder Creek was simulated as a leaky streambed. Leakage was stopped when the head in the aquifer declined below the head in the streambed at the individual river nodes. 

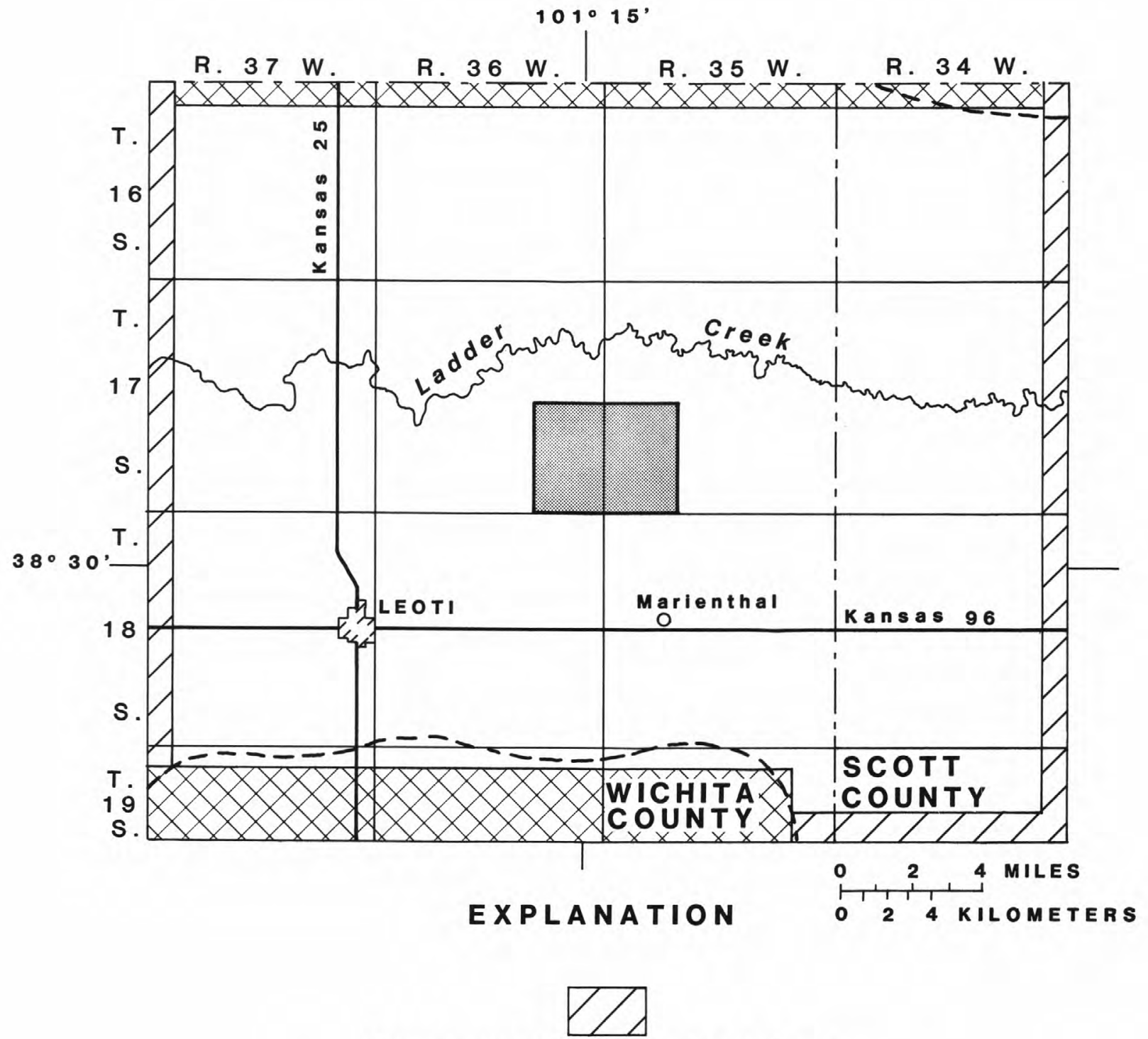

Constant-gradient boundary

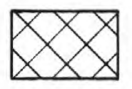

No-flow boundary

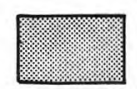

Intensive-study area

$$
\text { Aquifer boundary }
$$

Figure 20.--Boundary conditions during transient-state model. 


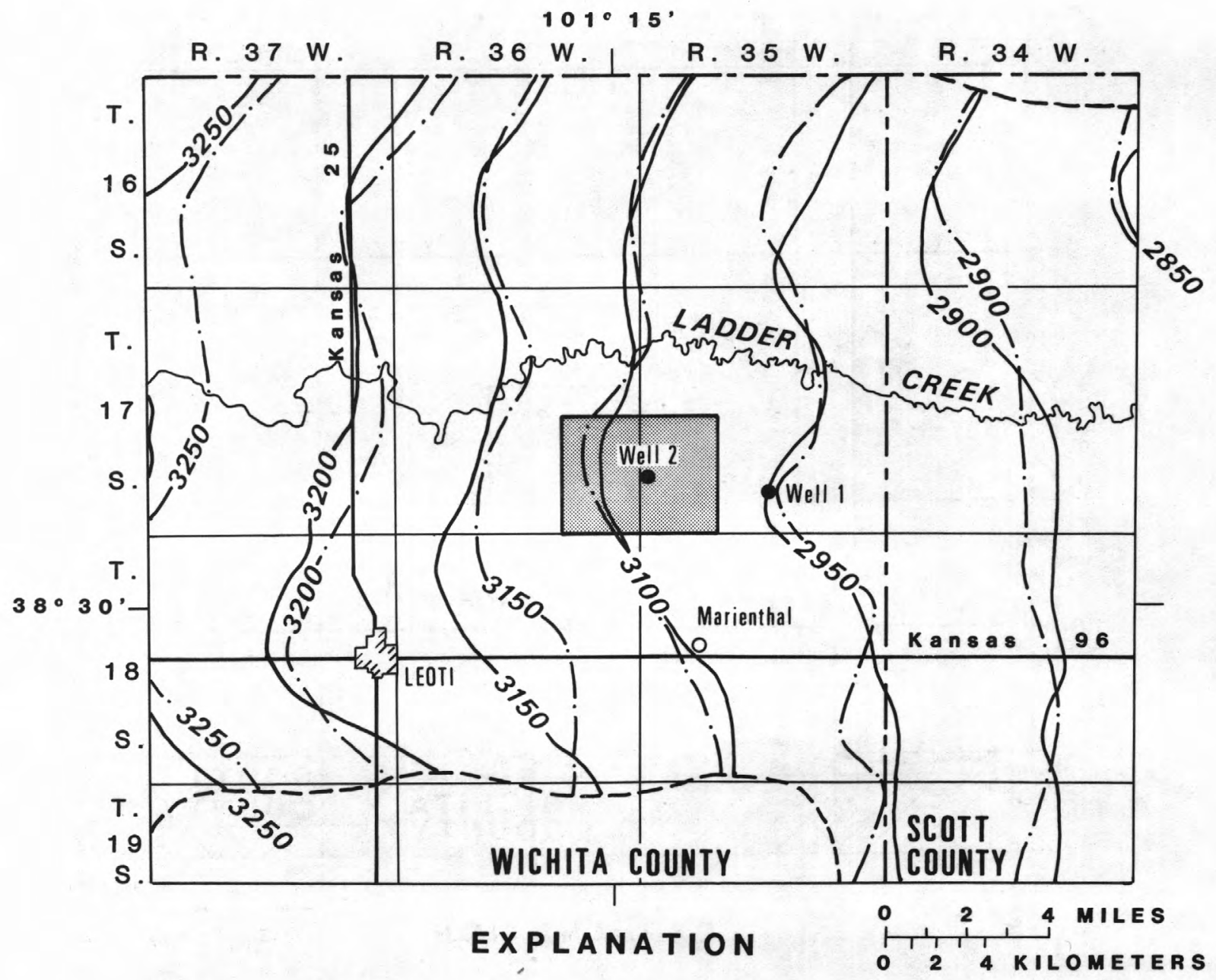

3150

Measured water-table contour

Shows altitude of water table, January 1978. Contour interval 50 feet. Datum is NGVD of 1929

Intensive-study area

$$
\text { Simulated water-table contour }
$$

Shows altitude of simulated water table, Aquifer boundary 1978. Contour interval 50 feet. Datum is NGVD of 1929

Figure 21.--Comparison of January 1978 water-table contours from measurements and from transient-state model. 
Using the parameters and boundary conditions as previously described, the model was calibrated by generating annual potentiometric surfaces for 1951-77. These computed surfaces were compared with measured potentiometric surfaces. The January 1978 water-table surface based on measurements and a simulated water-table surface are shown in figure 21. Hydrographs of measured water levels in wells in the model area (fig. 16) compared with hydrographs of water levels computed for that area near the well are shown in figure 22.

The method of calculating pumpage by crop consumptive use may be the reason that computed water levels are commonly higher than measured water levels during the late 1960's. Crop consumptive use calculates the amount of water required by a crop (available soil moisture at 50 percent). During the 1960's, farmers may have applied more water than required because the supply was considered to be plentiful and energy costs for pumping were relatively small. During the 1970 's, farmers may have applied less water due to increasing energy costs, declining water levels, and decreasing well yields.

Initial estimates of specific yield were based on data from well logs and aquifer tests. Calibration of the model under transient conditions indicated that a uniform specific yield of 0.17 best fit the measured water-1evel conditions. Other parameters, as determined from the steady-state model, were not adjusted during the calibration. However, pumpage and ground-water inflow and outflow were recalculated with each change in saturated thickness.

\section{Sensitivity Analysis}

When calibrating a model, there is always some degree of uncertainty about the accuracy of data in the model. Sensitivity of the model was examined by individually changing aquifer parameters and pumpage within their expected ranges and observing the changes in head. The parameters selected to test for sensitivity were specific yield, hydraulic conductivity, natural recharge, and pumpage. A section through the center of the area (column 13 in the model grid) was drawn to demonstrate changes in head. The sections shown in figure 23 represent the 1977 water-levels after the 1951-77 simulation period. Al though the changes in water levels are shown only for the section in column 13, inspection of other sections in the model grid indicated similar changes.

A specific yield of 0.17 , determined in the transient-state mode 1 , represents the calibrated value. A uniform increase in specific yield to 0.18 resulted in a maximum increase in head of 2.90 feet and an average increase of 2.02 feet per node in the section. A uniform decrease in specific yield to 0.15 resulted in a maximum decrease in head of 6.4 feet and an average decrease of 4.52 feet per node. 

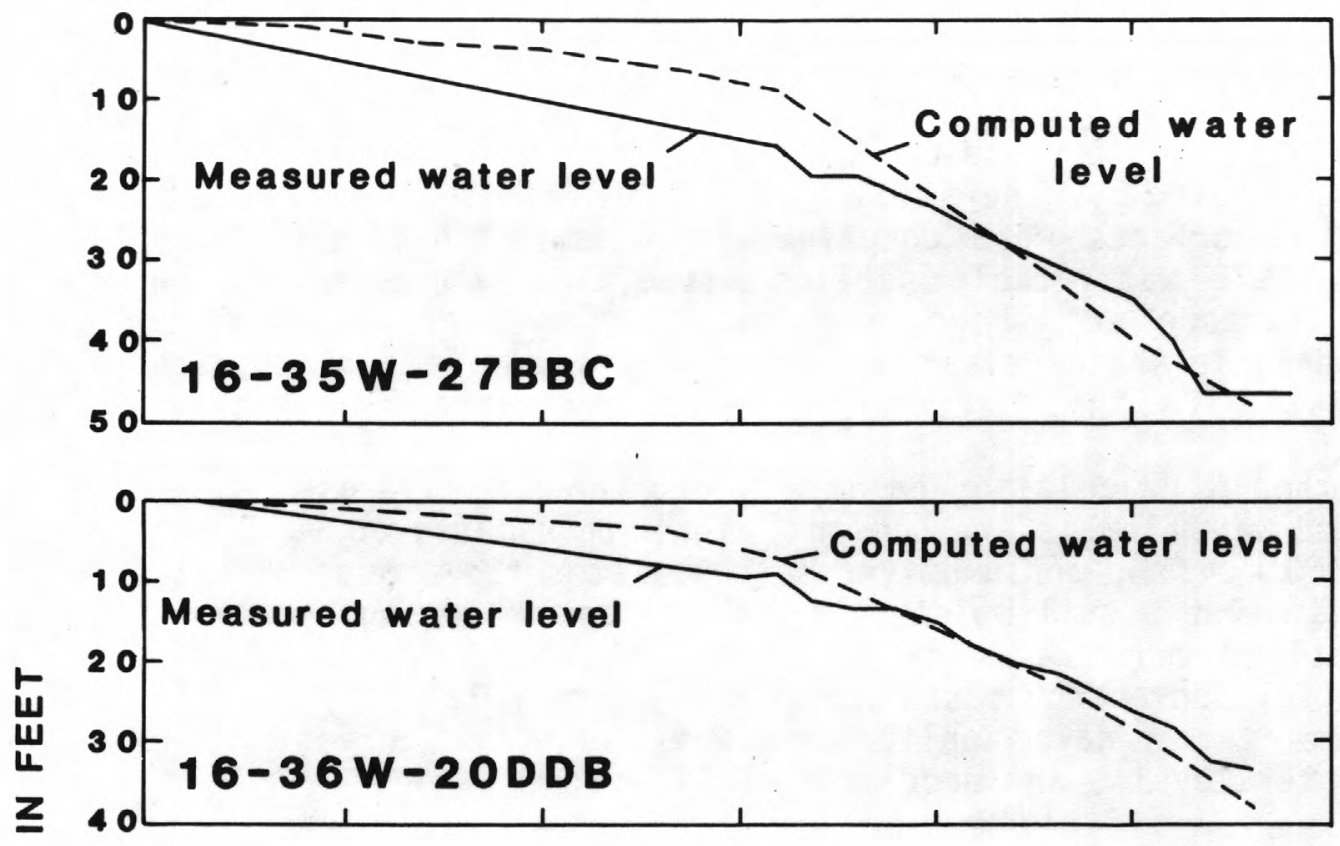

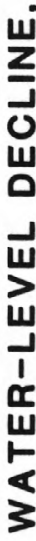
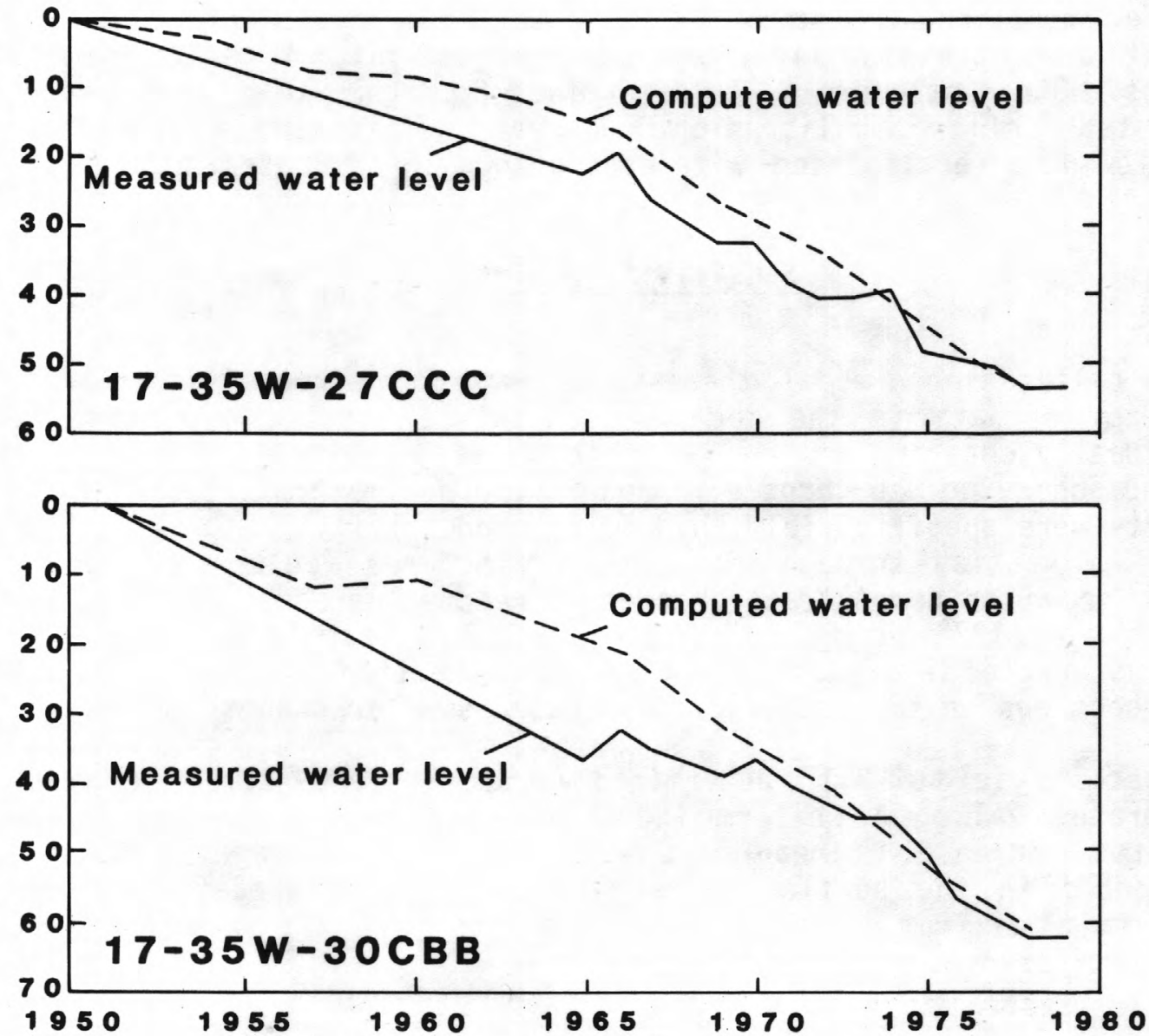

Figure 22.--Comparison of measured and computed water-level declines in selected wells. 

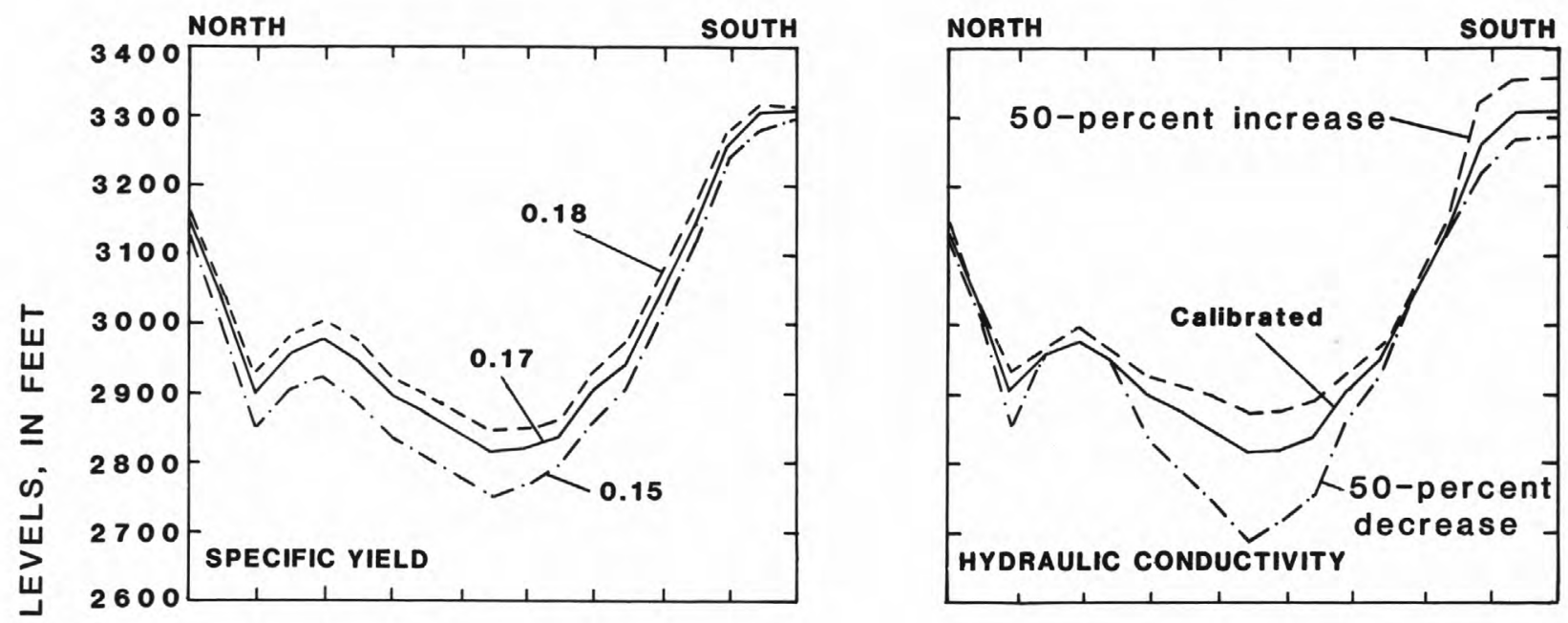

:
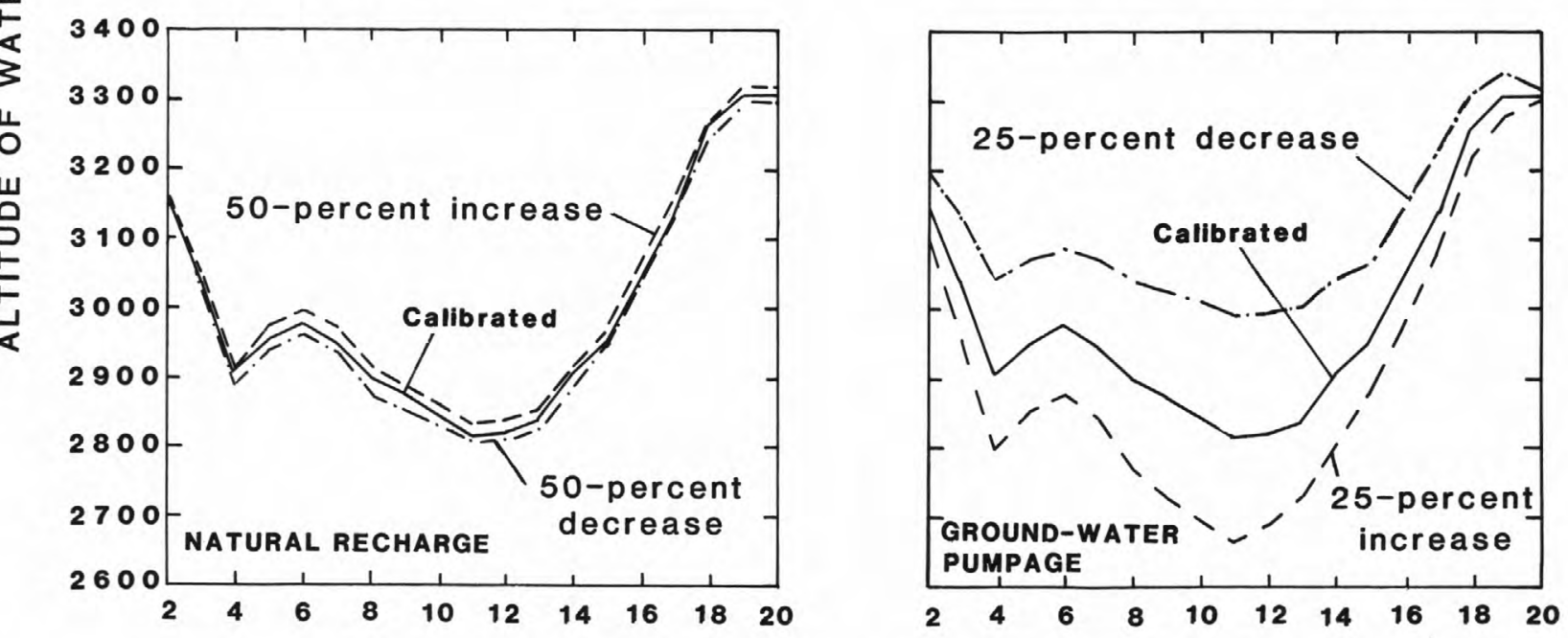

MODEL ROW

Figure 23.--Sections through center of column 13 in model grid showing sensitivity 1977 water levels to selected values for model parameters. 
A uniform 50-percent increase in the hydraulic conductivity resulted in a maximum increase in head of 5.5 feet and an average increase of 2.2 feet per node in the section. A uniform 50-percent decrease in the hydraulic conductivity resulted in a maximum decrease in head of 11.7 feet and an average decrease of 4.7 feet per node.

The calibrated value of natural recharge in the model was $0.28 \mathrm{in} / \mathrm{yr}$. A uniform 50-percent increase in this natural recharge resulted in a maximum increase in head of 2.0 feet and an average increase of 1.6 feet per node in the section. Likewise, a uniform 50-percent decrease in the natural recharge resulted in a maximum decrease in head of 2.0 feet and an average decrease of 1.6 feet per node.

The sensitivity analysis showed that changes in pumpage caused the greatest changes in head. A uniform 25-percent increase in pumpage resulted in a maximum decrease in head of 14.3 feet and an average decrease of 9.0 feet per node in the section. A uniform 25-percent decrease in the pumpage resulted in a maximum increase in head of 17.8 feet and an average increase of 11.4 feet per node.

Model Projections of Alternative Plans

After a transient-state mathematical model is calibrated to adequately simulate historical ground-water levels, different management alternatives can be tested to forecast future water-level trends with changes in simulated pumpage and recharge.

A series of model simulations were made for January 1978 to January 1989 using hypothetical pumpage in the model area. Various amounts of pumpage were used to test the amount of water-level decline that would occur in the intensive-study area during the 11-year interval. The pumpage calculated for 1977 was used in these projections because the annual rainfall during that year was near normal, and irrigation withdrawals were approximately equal to the average annual withdrawal during 1970-77. The pumpages were continued at the 1977 rate in all wells unless a decrease in saturated thickness to less than 50 feet required an adjustment by equation 3 .

Projections of the water-level declines in the intensive-study area are shown (fig. 24) for five different management plans. In plan A, it was assumed that all of the pumpage in the model area would be continued at the 1977 rate; in plan B, it was assumed that pumpage would be reduced to one-half of the 1977 rate; in plan C, it was assumed that pumpage would be increased to double the 1977 rate. In plans $D$ and $E$, it was assumed that most of the pumpage in the model area would be continued at the 1977 rate, while pumpage in the intensivestudy area would be reduced to one-half of the 1977 rate (plan D) or would be increased to double the 1977 rate (plan E). 
Plan A might be considered as a management alternative to maintain irrigation at the 1977 level of development. In this plan, it was assumed that all pumpage in the model area would be allowed to continue at the 1977 rate. Also, it was assumed that no new wells would be installed and irrigated acreage would remain unchanged. This projection (fig. 24) indicates that 15 to 30 feet of water-level decline would occur in the intensive-study area during 11 years.

Plan B might be considered as a possible management alternative designed to reduce the amount of water applied wi thout substantially reducing crop acreage. Studies by the Kansas State Experiment Station in Tribune, Kansas (Gwin and Gallagher, 1979, p. 39-43), showed that corn production was reduced 65 percent when the amount of water applied was 40 percent less than that applied to fully irrigated corn. Production of grain sorghum was reduced only 4 percent when the amount of water applied was 48 percent less than that applied to fully irrigated grain sorghum. Thus, a 50-percent reduction in ground-water withdrawal might be feasible if grain sorghum became the dominant crop in the modeled area.

In $\mathrm{plan} B$, it was assumed that all pumpage in the model area would be reduced to one-half of the 1977 rate, and the number of wells and irrigated acreage would remain constant. This projection indicates that there would be 5 to 15 feet of water-level decline in the intensive-study area, which is one-half the decline in $\mathrm{Plan} A$.

Plan C might be considered to represent conditions that could occur if the management alternative pernitted unrestricted development. In this plan, it was assumed that every irrigator in the model area increased pumpage to double the 1977 rate by installing twice the number of wells to irrigate additional 1 and. This projection indicates that there would be 25 to 40 feet of water-1evel decline.

Plan D might be considered as a management alternative to alleviate waterlevel declines by reducing the pumpage in a small "control area." In plan D, the intensive-study area was simulated as a control area by reducing pumpage to one-half of the 1977 rate while the number of wells and irrigated acreage remained constant. In $\mathrm{plan} D$, it was assumed that wells outside the control area would be pumped at the 1977 rate. The projection indicates there would be 10 to 25 feet of water-level decline in the intensive-study area. Results show the declines to be less than those in plan A and more than those in plan B. Continued pumpage at the 1977 rate of wells in the surrounding model area would cause greater water-level declines in wells near the border of the control area and smaller declines in wells near the center.

Plan E might be considered to represent conditions that could occur if the the management alternative permitted unrestricted development in a small area (the intensive-study area). In plan $E$, it was assumed that pumpage from wells in the intensive-study area would be increased to double the 1977 pumpage rate and that wells outside the intensive-study area would continue to pump at the 1977 rate. This projection indicates that the water-level decline from doubling the pumpage in only the intensive-study area would not be as great as it would be if all wells in the model area doubled their pumpage rate (plan C). Thus, increased pumpage in the unrestricted area would induce water movement from outside the intensive-study area. The result would be smaller water-level declines in wells near the border of the intensive-study area than in those wells near the center. 


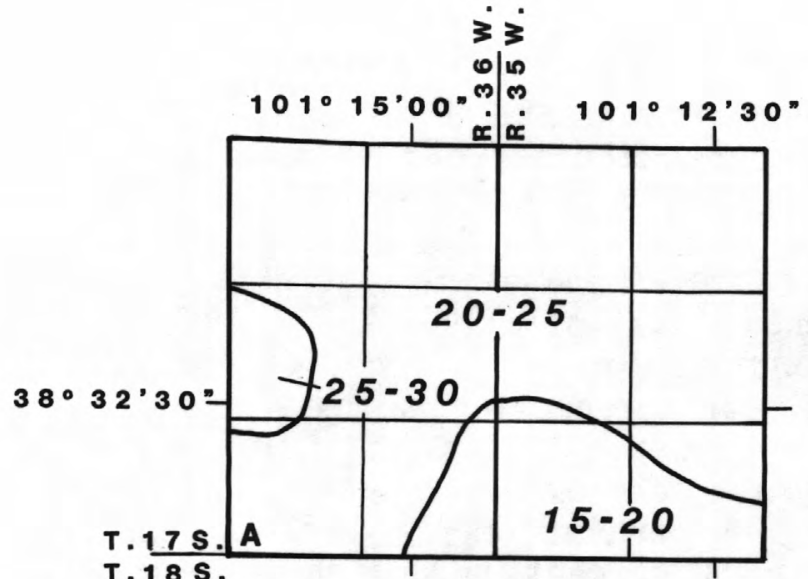

$\mathrm{T} .18 \mathrm{~S}$.
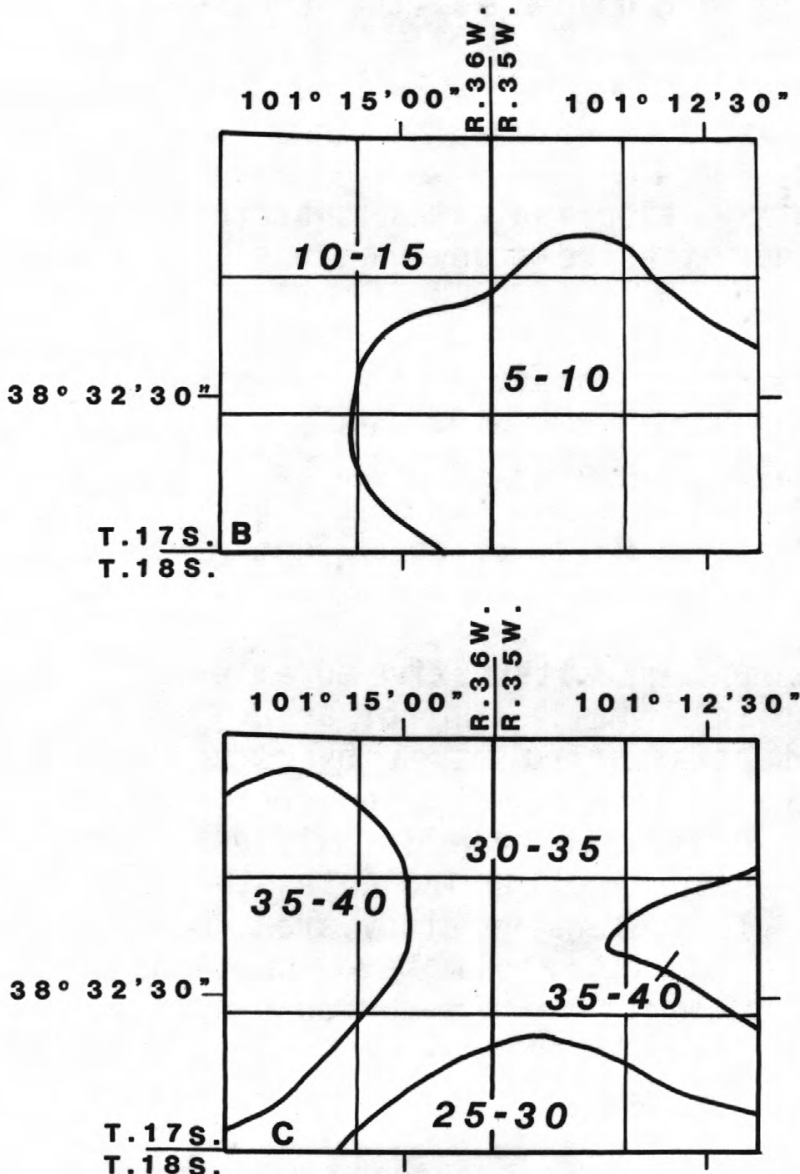

EXPLANATION

$$
\text { 20-25 }
$$

Area of equal water-level decline, in feet
A. Pumpage in model area continued at 1977 rate

B. Pumpage in model area reduced to one-half 1977 rate

C. Pumpage in model area increased to double 1977 rate 


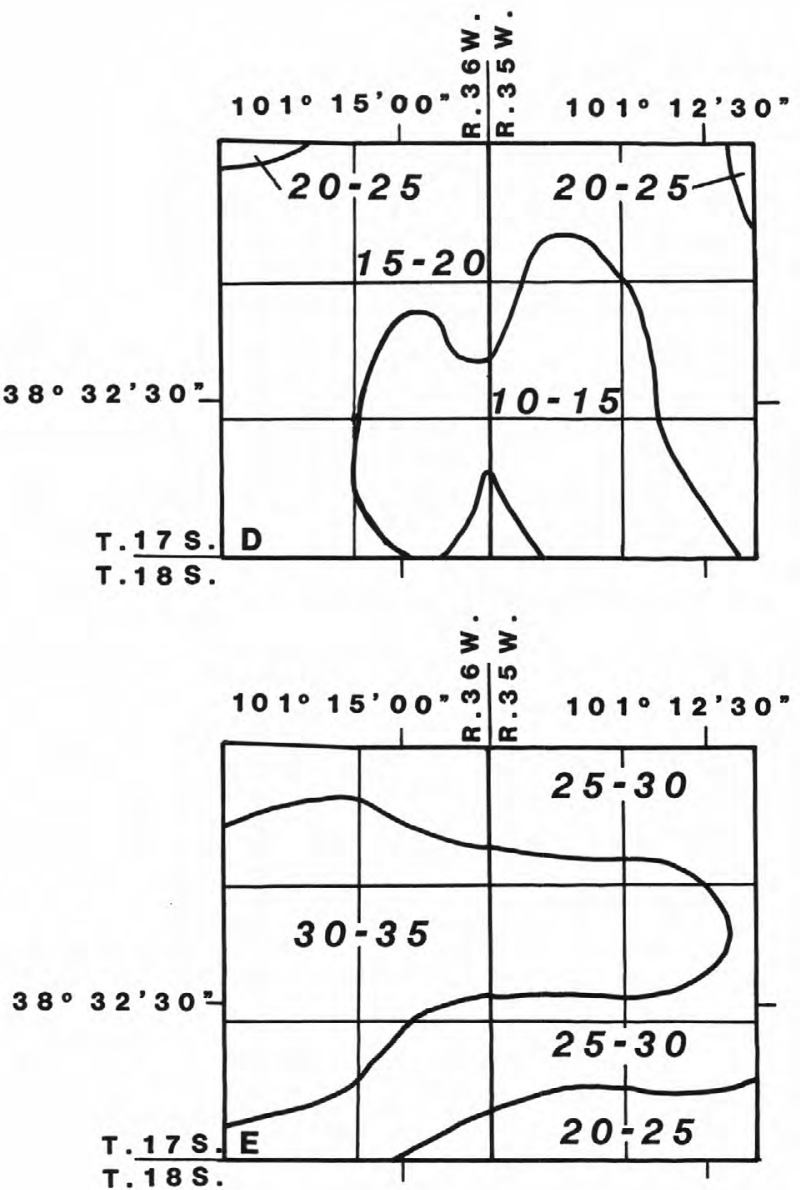

D. Pumpage in intensive-study area reduced to one-half 1977 rate

E. Pumpage in intensive-study area increased to double 1977 rate

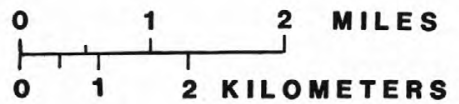

Figure 24.--Simulated water-level declines in the intensive-study area resulting from selected pumpage rates in the model area. 
The additional water-level decline and saturated thickness of three hypothetical wells in the intensive-study area from January 1978 to January 1989 are shown in figure 25. The five different hydrographs for each well represent the five alternative management plans. The hydrographs show the additional decline that would occur if all wells in the model area were pumped at the 1977 rate (plan A), one-half the 1977 rate (plan B), or double the 1977 rate (plan C). The hydrographs also show the additional decline that would occur if wells in the model area were pumped at the 1977 rate and wells in the intensive-study area were pumped at one-half the 1977 rate (plan D) or double the 1977 rate (plan E).

\section{SUMMARY AND CONCLUSIONS}

The gradual depletion of ground-water reserves has resulted in concern for the agricultural economy of west-central Kansas. The annual water-level decline in the intensive-study area during 1950-78 ranged from 1.08 to $2.22 \mathrm{ft} / \mathrm{yr}$. The total water-level decline during this period ranged from 30.10 to 62.24 feet and averaged 47.84 feet. The ground-water pumpage in the intensive-study area has caused a depression in the water-table surface that has resulted in distortion of the general eastward flow pattern in Wichita County. The average saturated thickness decreased from 115 feet during 1950 to 67 feet during 1978.

Ground water in storage in the intensive-study area amounted to 61,000 acre-ft during 1977, not all of which is recoverable. The instantaneous irrigationwell discharge during 1976-78 ranged from 65 to 1,080 gal/min and averaged 450 gal/min. About 6,800 acre-ft of ground water was pumped during 1977 (a wet year), and 7,900 acre-ft of water was pumped during 1978 (a dry year).

Soil-moisture data collected from a gravity-irrigated test field showed that soil moisture was usually adequate at the end of the field where water is applied and in the area where tailwater stands. Soil moisture was inadequate in the middle of the field because the irrigation-run distance $(0.5$ mile) was too long.

With the use of a digital computer model, water levels were projected for different management alternatives. If the management policy would allow pumpage to continue at 1977 rates, the projection indicates that 15 to 30 feet of additional water-level decline would occur in the intensive-study area in the next 11 years. If the management policy would reduce all pumpage in the model area to one-half of the 1977 rate, the projection indicates that water levels would decline 5 to 15 feet in the intensive-study area in the next 11 years. Control areas might be designed to alleviate water-level declines by reducing the quantity of water pumped in a small area. If pumpage from wells in the model area was continued at the 1977 rate and pumpage in the control area was reduced to one-half the 1977 rate, a decline of 10 to 25 feet probably would occur. However, declines near the edge of a control area would be greater than those near the center as a result of continued pumpage from wells outside the area boundary.

The digital model was more sensitive to changes in pumpage than to changes in hydraulic conductivity, specific yield, and recharge. 

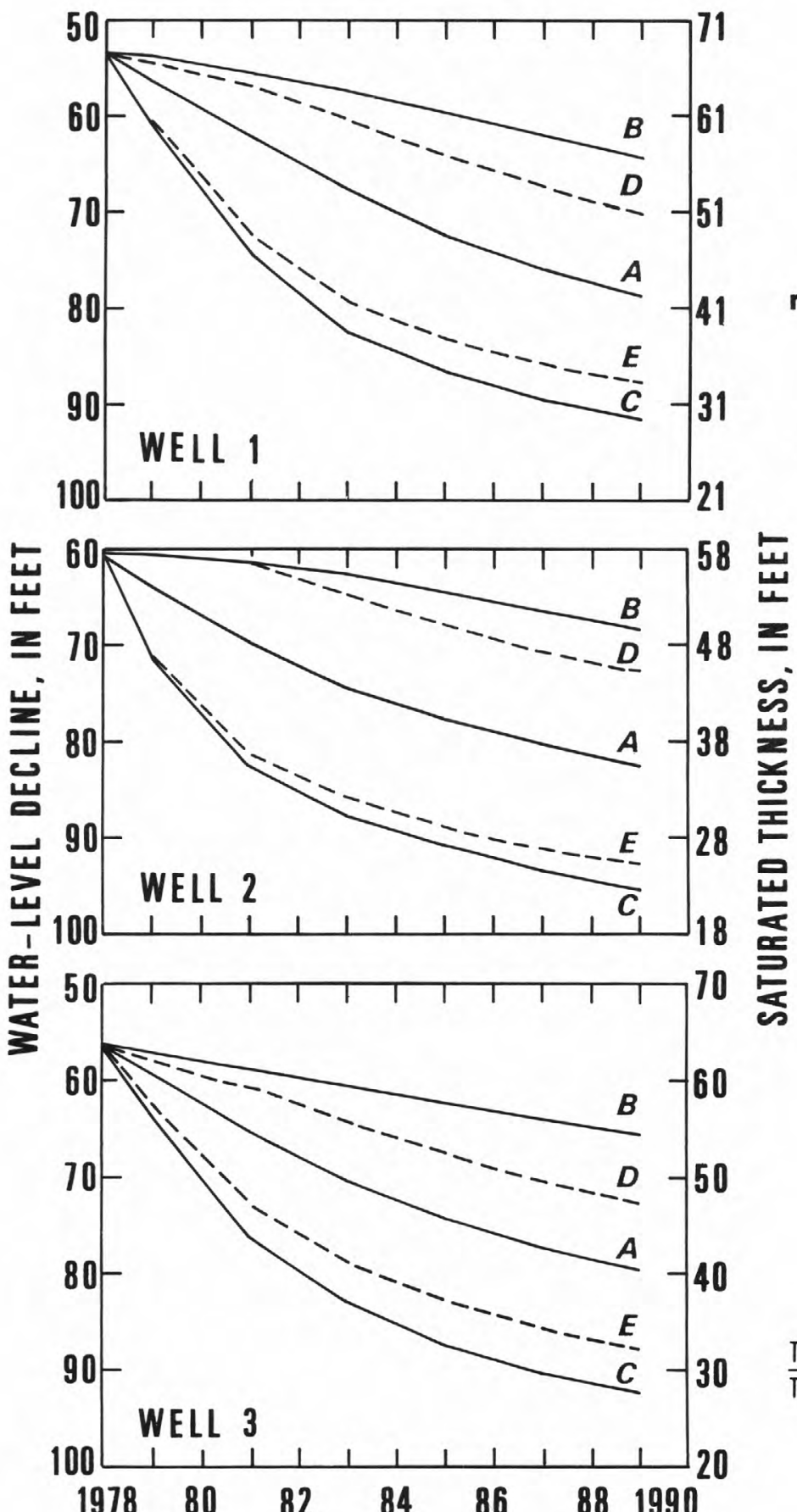

$\begin{array}{lllllll}1978 & 80 & 82 & 84 & 86 & 88 & 1990\end{array}$

\section{EXPLANATION}

$A$

Pumpage in model area continued at 1977 rate

Pumpage in model area reduced to one-half 1977 rate C

Pumpage in model area increased to double 1977 rate

$$
----D----
$$

Pumpage in intensive-study area reduced to one-half 1977 rate -----E----

Pumpage in intensive-study area increased to double 1977 rate

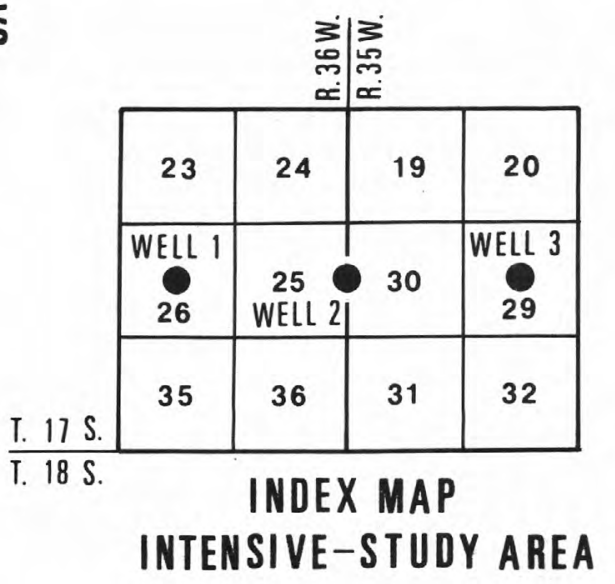

Figure 25.--Simulated water-level declines in three hypothetical wells in the intensive-study area resulting from different pumpage projections. 
Bradley, Edward, and Johnson, C. R., 1957, Ground-water resources of the Ladder Creek area in Kansas: Kansas Geological Survey Bulletin 126, 194 p.

Broeker, M. E., and McNellis, J. M., 1973, Ground-water levels in observation wells in Kansas, 1966-70: Kansas Geological Survey Basic Data Series, Ground-Water Release No. 3, 373 p.

Broeker, M. E., McIntyre, H. J., Jr., and McNellis, J. M., 1977, Ground-water levels in observation wells in Kansas, 1971-75: Kansas Geological Survey Basic Data Series, Ground-Water Release 6, 526 p.

Gutentag, E. D., 1976, Map showing percent change in saturated thickness of unconsolidated aquifer, 1950-76, west-central Kansas: U.S. Geological Survey Open-File Report 76-457.

Gutentag, E. D., Lobmeyer, D. H., and McGovern, H. E., 1972, Ground water in Kearny County, southwestern Kansas: U.S. Geological Survey Hydrologic Investigations Atlas HA-416.

Gutentag, E. D., and Stullken, L. E., 1976, Ground-water resources of Lane and Scott Counties, western Kansas: Kansas Geological Survey Irrigation Series No. 1, $37 \mathrm{p}$.

Gwin, R. E., and Gallagher, P. J., 1979, Limited irrigation studies with corn and grain sorghum, Tribune, Kansas: Proceedings of Irrigation Workshop, Cooperative Extension Service, Kansas State University, p. 39-43.

Hathaway, L. R., Magnuson, L. M., Carr, B. L., Galle, 0. K., and Waugh, T. C., 1975, Chemical quality of irrigation waters in west-central Kansas: Kansas Geological Survey Chemical Quality Series 2, 46 p.

Johnson, M. S., 1978, The hydrogeology of an area near Marienthal, Wichita County, Kansas: Manhattan, Kans., Kansas State University unpublished M.S. thesis, $62 \mathrm{p}$.

Kansas State Board of Agriculture, 1951-75, Kansas Agriculture - Annual Report.

Kume, Jack, Dunlap, L. E., Gutentag, E. D., and Thomas, J. G., 1979, Hydrologic and related data for water-supply planning in an intensive-study area, northeastern Wichita County, Kansas: U.S. Geological Survey WaterResources Investigations $79-105,51 \mathrm{p}$.

Lappala, E. G., 1978, Quantitative hydrogeology of the Upper Republican Natural Resources District, southwest Nebraska: U.S. Geological Survey WaterResources Investigations 78-38, 209 p.

McGuinness, C. L., 1964, Generalized map showing annual runoff and productive aquifers in the conterminous United States: U.S. Geological Survey Hydrologic Investigations Atlas HA-194. 
Pabst, M. E., 1978, Map showing percentage decrease in saturated thickness of unconsolidated aquifer, 1950-78, west-central Kansas: U.S. Geological Survey Open-File Report 78-874.

1979, Maps showing saturated thickness, January 1979, and percentage decrease in saturated thickness, 1950-79, of unconsolidated aquifer, westcentral Kansas: U.S. Geological Survey Open-File Report 79-1340.

Pabst, M. E., and Gutentag, E. D., 1977, Water-1evel changes in west-central Kansas, 1950-77: Kansas Geological Survey Journal, October 1977, 18 p.

Pabst, M. E., and Jenkins, E. D., 1974, Water-1evel changes in west-central Kansas, 1950-74: Kansas Geological Survey Journal, October 1974, 15 p.

Prescott, G. C., Jr., Branch, J.R., and Wilson, W. W., 1954, Geology and groundwater resources of Wichita and Greeley Counties, Kansas: Kansas Geological Survey Bulletin 108, $134 \mathrm{p}$.

Trescott, P. C., Pinder, G. F., and Larson, S. P., 1976, Finite-difference model for aquifer simulation in two dimensions with results of numerical experiments: U.S. Geological Survey Techniques of Water-Resources Investigations, book 7, chap. C-1, 116 p.

Sanghi, A. K., and Klepper, Robert, 1977, Economic impact of diminishing groundwater reserves on corn production under center-pivot irrigation: Journal Soil and Water Conservation, November-December, p. 282-285.

Slagle, S. E., and Weakly, E. C., 1976, Ground-water resources of Greeley and Wichita Counties, western Kansas: Kansas Geological Survey Irrigation Series No. 2, 21 p.

Stullken, L. E., Weakly, E. C., Gutentag, E. D., and Slagle, S. E., 1974, Hydrogeologic data from Greeley, Wichita, Scott, and Lane Counties, Kansas: Kansas Geological Survey Basic Data Series, Ground-Water Release No. 4, $58 \mathrm{p}$.

U.S. Department of Commerce, 1977, Climatological data for Kansas - Annual Summary: v. 91 , no. $13,18 \mathrm{p}$.

1978, Climatological data for Kansas - Annual Summary: v. 92, no. 13, $18 \mathrm{p}$.

U.S. Salinity Laboratory Staff, 1954, Diagnosis and improvement of saline and alkali soils: U.S. Department of Agriculture, Agriculture Handbook 60, $160 \mathrm{p}$. 
